\title{
Host Defence Peptide LL-37 Induces IL-6 Expression in Human Bronchial Epithelial Cells by Activation of the NF-KB Signaling Pathway
}

\author{
Jelena Pistolic ${ }^{a} \quad$ Celine Cosseau ${ }^{a} \quad$ Yuexin $\mathrm{Li}^{\mathrm{a}} \quad$ Jie (Jessie) $\mathrm{Yu}^{\mathrm{a}}$ Niall C.J. Filewod ${ }^{\mathrm{a}}$ \\ Shaan Gellatly ${ }^{a}$ Linda M. Rehaume ${ }^{a}$ Dawn M.E. Bowdish ${ }^{b}$ \\ Robert E.W. Hancock ${ }^{a}$ \\ ${ }^{a}$ Department of Microbiology and Immunology, University of British Columbia, Vancouver, B.C., Canada; \\ ${ }^{b}$ Sir William Dunn School of Pathology, University of Oxford, Oxford, UK
}

\section{Key Words}

Bronchial epithelial cells $\cdot \mathrm{IL}-6 \cdot \mathrm{LL}-37 \cdot \mathrm{NF}-\mathrm{kB}$

\begin{abstract}
LL-37, the only member of the cathelicidin family of cationic host defence peptides in humans, has been shown to mediate multiple immunomodulatory effects and as such is thought to be an important component of innate immune responses. A growing body of evidence indicates that LL-37 affects lung mucosal responses to pathogens through altered regulation of cell migration, proliferation, wound healing and cell apoptosis. These functions are consistent with LL-37 playing a role in regulating lung epithelial inflammatory responses; however, that role has not been clearly defined. In this report we have demonstrated that host defence peptide LL-37 induced cytokine (IL-6) and chemokine (CXCL$1 /$ GRO- $\alpha$ and CXCL-8/IL-8) release from human bronchial epithelial cells. It was demonstrated that LL-37-mediated IL-6 release was time and dose dependent and that LL-37 up-regulated this pleiotropic cytokine at the transcriptional level. Using specific inhibitors it was shown that NF- $\mathrm{KB}$ signaling led to the LL-37-stimulated production of IL-6. LL-37 stimulation of airway epithelial cells activated NF-KB signaling, as demonstrated by the phosphorylation and degradation of $1 \kappa-B \alpha$, and consequent nuclear translocation of $\mathrm{p} 65$ and $\mathrm{p} 50$
\end{abstract}

NF- $\kappa B$ subunits. Furthermore this host defence peptide augmented flagellin-mediated cytokine production, indicating that LL-37 likely modulates Toll-like receptor 5-mediated responses.

Copyright $\odot 2008$ S. Karger AG, Basel

\section{Introduction}

Cationic host defence peptides, including cathelicidins, are a widely expressed peptide group characterized by a multitude of functions including anti-cancer, antimicrobial, wound healing and innate immunity-modulating activities [1-4]. The sole human cathelicidin, LL37 , is expressed in a variety of cell types and tissues in the human body. It is abundant in neutrophils and has been shown to be expressed in macrophages, monocytic cells, B cells, subsets of T cells, skin mast cells, as well as numerous epithelial sites under homeostatic and inflammatory conditions [5-15]. In the lung, expression of LL-37 has been demonstrated in respiratory epithelial cells of proximal and distal airways, as well as the cells of submucosal glands $[9,10,16]$. Several studies have reported an increase of LL-37 in bronchio-alveolar lavage fluid from patients suffering from a number of pathological lung conditions such as cystic fibrosis, sarcoidosis and chron-

\section{KARGER \\ Fax +4161306 1234 E-Mail karger@karger.ch} www.karger.com
Dr. Robert E.W. Hancock

Department of Microbiology and Immunology

University of British Columbia

Vancouver, BC, V6T 1 Z3 (Canada)

Tel. +1 604822 2682, Fax +1 604827 5566, E-Mail bob@cmdr.ubc.ca 
ic obstructive pulmonary disease (COPD) $[9,10,16,17]$ as well as in infants with infections [18]. The widespread distribution of this peptide and its induction during inflammation indicates that it plays a highly relevant role in lung immune defence mechanisms, although this role is not yet fully understood.

As various in vitro and in vivo studies show, LL-37 is a potent inducer of numerous immunomodulatory activities. It can mediate chemotaxis of a variety of cell types [19-21], modulate apoptosis in neutrophils and epithelial cells [22-24], affect mast cell function [25, 26], modulate endotoxin signaling and responses [22, 27-29], promote wound healing, angiogenesis and vasodilation [30-36], influence dendritic cell (DC) activation and function $[37,38]$ and induce chemokine/cytokine production in many cell types [30, 39-45].

In the lung, overexpression studies associate a prominent increase in peptide concentration during inflammation with improved clearance of pulmonary pathogens, which is consistent with the hypothesis that LL-37 is a significant effector molecule of lung immune responses $[46,47]$. In in vitro studies, LL-37 has been shown to induce IL-8 production from bronchial epithelial cells in a dose- and time-dependent manner and to promote mitogen-activated protein kinase (MAPK) activation (ERK$1 / 2$, p38, JNK) $[39,41,48]$. Furthermore, LL-37 is able to induce proliferation, migration and wound healing in bronchial epithelial cells in a serum-dependent manner at relatively low concentrations [31].

LL-37 engages intricate mechanisms of action and signaling regulation to exert a wide range of functions in a variety of cell types. To date, three receptors have been proposed to mediate the effects of LL-37 on various cells, namely epidermal growth factor receptor (EGFR), a Gprotein-coupled formyl peptide receptor-like-1 (FPRL-1) and a purinergic $\mathrm{P}_{2} \mathrm{X}_{7}$ receptor $[21,41,49]$. The role of EGFR in peptide-mediated lung mucosal responses was shown to be particularly relevant in the regulation of ERK-1/2 activation and IL-8 production [41], as well as wound closure and proliferation in lung epithelial cells [30, 31]. Various signaling pathways have been demonstrated to be activated and regulated by LL-37 in leucocytes. These include the phosphoinositide 3-kinases (PI3K), MAPK, protein kinase $\mathrm{C}$ and NF- $\kappa \mathrm{B}$ pathways in the regulation of angiogenesis [34], MAPK pathways in the induction of chemokines [39], Toll-like receptor (TLR) 4 to NF- $\mathrm{KB}$ signaling in the modification of endotoxin responses [27], NF- $\kappa \mathrm{B}$ and PI3K/cAMP-responsive element binding protein (CREB) signaling in synergistic induction of cytokines/chemokines [42] and PI3K path- ways in the regulation of neutrophil apoptosis inhibition $[22,24]$. However, our knowledge of LL-37-modulated signaling pathway regulation in airway epithelia is somewhat limited.

In this study we have investigated effects of host defence peptide LL-37 on human airway epithelial cells. We observed LL-37-stimulated cytokine and chemokine release from human airway epithelial cells. In particular, LL-37-mediated transcription and secretion of IL- 6 was dose and time dependent. Furthermore, we demonstrated that LL-37 activated the NF- $\kappa \mathrm{B}$ signaling pathway, through evaluation of Iк-B $\alpha$ phosphorylation/degradation and NF- $\kappa \mathrm{B}$ p50/p65 nuclear subunit translocation. This NF- $\kappa$ B signaling activation was shown to regulate IL- 6 release from airway epithelial cells. In addition, simultaneous airway epithelial cell stimulation with LL-37 and flagellin induced augmented cytokine/chemokine signatures, indicating that this host defence peptide can modulate TLR5 signaling responses in these cells. This demonstrated that the interaction of LL-37 and NF- $\mathrm{KB}$ signaling mediates epithelial cell immune responses.

\section{Materials and Methods}

\section{Cell Culture}

The SV40-transformed, immortalized human bronchial epithelial (HBE) cell line $16 \mathrm{HBE}_{14 \mathrm{o}^{-}}$was a gift from Dr. D. Gruenert (University of California, San Francisco, Calif., USA) [50]. $16 \mathrm{HBE} 14 \mathrm{o}^{-}$cells were cultured in minimum essential medium (MEM) with Earle's salts (Life Technologies Invitrogen), supplemented with $10 \%$ heat-inactivated fetal bovine serum (FBS; Life Technologies Invitrogen) and $2 \mathrm{mM}$ L-glutamine (Life Technologies Invitrogen). $16 \mathrm{HBE} 14 \mathrm{o}^{-}$cells were routinely cultured to $85-$ $90 \%$ confluence in $100 \%$ humidity and $5 \% \mathrm{CO}_{2}$ at $37^{\circ} \mathrm{C}$ and were used between passages 5 and 15 .

Clonetics primary normal HBE (NHBE) cells were purchased from Cambrex BioScience (Walkersville, Md., USA) and cultured and maintained in bronchial epithelial growth medium (BEGM; Cambrex BioScience), according to the manufacturer's instructions. BEGM is a basal medium (Cambrex BioScience) supplemented with bronchial epithelial cell SingleQuots growth factors and supplements (Cambrex BioScience), and is used as a serum substitute optimized for growth and appropriate differentiation of these primary cells. SingleQuots includes human EGF, triiodothyronine, bovine pituitary extract, epinephrine, transferrin, insulin, hydrocortisone, gentamicin/amphotericin and retinoic acid. In accordance with the manufacturer's instructions, cells were cultured in complete BEGM to $85-90 \%$ confluence in $100 \%$ humidity and $5 \% \mathrm{CO}_{2}$ at $37^{\circ} \mathrm{C}$, and were used between passages 3 and 10.

Peptides, Inhibitors, Antibodies and Other Reagents

LL-37 (sequence LLGDFFRKSKEKIGKEFKRIVQRIKDFLRNLVPRTES) was synthesized by $N$-(9-fluorenyl)methoxy car- 
bonyl (F-moc) chemistry at the Nucleic Acid/Protein Synthesis Unit at the University of British Columbia. Human recombinant interleukin-1 $\beta$ (IL-1 $\beta$ ) was purchased from Research Diagnostics (Flanders, N.J., USA). The NF- $\mathrm{B}$ inhibitor parthenolide, EGFR inhibitor AG1478, MEK inhibitor PD98059, p38 inhibitor SB203580, JNK inhibitor SP600125, PI3K inhibitor LY294002 and G-protein-coupled receptor inhibitor pertussis toxin (PTX) were purchased from Calbiochem (San Diego, Calif., USA). The NF-кB inhibitor Bay 11-7085 was purchased from Biomol International (Plymouth Meeting, Pa., USA). The DeadEnd Fluorometric TUNEL System was purchased from Promega (Madison, Wisc., USA). Mouse monoclonal antibody anti-phospho-Iк-B $\alpha$ and anti-GAPDH, rabbit anti-total-Iк-B $\alpha$, anti-p50, anti-p65 and HRP-conjugated goat anti-rabbit antibodies were purchased from Cell Signaling Technology (Danvers, Mass., USA). The antimouse IgG antibody was purchased from Amersham (Piscataway, N.J., USA), while the mouse anti-H2AX histone antibody was purchased from R\&D Systems (Minneapolis, Minn., USA). Lipopolysaccharide (LPS) from Pseudomonas aeruginosa PA01strain H103 was purified free of proteins and lipids using the DarveauHancock method as described previously [51]. Salmonella typhimurium flagellin was purchased from Cedarlane Laboratories (Burlington, Ont., Canada).

\section{Detection of Cytokines and Chemokines}

$16 \mathrm{HBE} 14 \mathrm{o}^{-}$cells were seeded in 24-well plates (Sarstedt, Montreal, Qué., Canada) in 10\% FBS/2 mM L-glutamine MEM at a concentration of $1.5 \times 10^{5}$ cells $/ \mathrm{ml}(1 \mathrm{ml}$ per well), and cultured at $37^{\circ} \mathrm{C}$ and $5 \% \mathrm{CO}_{2}$ for 2 days to achieve confluence. Unless otherwise indicated, cells were treated in MEM supplemented with $2 \%$ FBS and $2 \mathrm{mM}$ L-glutamine. When confluent, cells were washed with $1 \mathrm{ml}$ per well of serum-free MEM, and then $1 \mathrm{ml}$ of $2 \% \mathrm{FBS} / 2 \mathrm{mM} \mathrm{L}$-glutamine MEM was added to each well. If chemical inhibitors were used, they were first dissolved in $2 \%$ FBS MEM, and then added to the cells after the washing step. Cells were rested for $1 \mathrm{~h}$, and were subsequently treated with peptide or other stimuli. After the desired incubation time, supernatants were collected and stored at $-20^{\circ} \mathrm{C}$ in aliquots.

Primary NHBE cells were seeded at $5 \times 10^{4}$ cells $/ \mathrm{ml}(1 \mathrm{ml}$ per well) in 24-well plates (Sarstedt) in complete BEGM, and were cultured at $37^{\circ} \mathrm{C}$ and $5 \% \mathrm{CO}_{2}$. When confluent, cells were washed with $1 \mathrm{ml}$ per well of Hepes-buffered salt solution (Cambrex BioScience), and then $1 \mathrm{ml}$ of complete BEGM (without EGF) was added to each well. Cells were rested for $1 \mathrm{~h}$ and were subsequently treated with the peptide or other stimuli. After the desired incubation time, supernatants were collected and stored at $-20^{\circ} \mathrm{C}$ in aliquots.

The concentrations of IL-8, IL- 6 , GRO- $\alpha$, RANTES, TNF- $\alpha$, IL-1 $\beta$, IP-10, MIP- $1 \alpha$ and IL-10 in cell culture supernatants were measured using an enzyme-linked immunosorbent assay (ELISA) as per the manufacturer's suggestion (GRO- $\alpha$, IP-10 and RANTES ELISA from R\&D; TNF- $\alpha$, IL- $1 \beta$, IL-10 and IL-6 ELISA from eBioscience, San Diego, Calif., USA, and IL- 8 and MIP- $1 \alpha$ ELISA from BioSource International, Camarillo, Calif., USA).

\section{RNA Isolation and Real-Time PCR}

$16 \mathrm{HBE}_{14 \mathrm{o}^{-}}$cells were seeded in $15 \times 30 \mathrm{~mm}$ plates (Sarstedt) at $2.8 \times 10^{5}$ cells $/ \mathrm{ml}$, and cultured to sub-confluence at $37^{\circ} \mathrm{C}$ and $5 \% \mathrm{CO}_{2}$ in $10 \% \mathrm{FBS} / 2 \mathrm{mM}$ L-glutamine MEM for 2 days. On the day of treatment, sub-confluent cells were washed with $1 \mathrm{ml} /$ plate of serum-free MEM, and $1 \mathrm{ml}$ of $2 \% \mathrm{FBS} / 2 \mathrm{mM}$ L-glutamine-supplemented MEM was added. After the medium change, cells were rested for $1 \mathrm{~h}$ and subsequently treated with various stimuli over a time course of 1,2 and $4 \mathrm{~h}$. Total RNA was isolated using the RNeasy Mini kit (Qiagen, Gaithersburg, Md., USA), as per the manufacturer's instructions, and was DNAse treated using the RNase-free DNase kit (Qiagen). Once RNA integrity was confirmed by $1 \%$ agarose electrophoresis and spectrophotometry, $1 \mu \mathrm{g}$ of total RNA was converted to cDNA as per the manufacturer's instructions using the SuperScript III Platinum CellsDirect Two-step qRT-PCR kit with SYBR Green (Invitrogen), with a nontemplate negative control for each of the treatments. Quantitative real-time PCR was done using the ABI Prism 7000 system, including a dissociation curve program, at $50^{\circ} \mathrm{C}$ for $2 \mathrm{~min}, 95^{\circ} \mathrm{C}$ for $2 \mathrm{~min}$, then $50 \mathrm{cycles}$ at $95^{\circ} \mathrm{C}$ for $15 \mathrm{~s}$ and $60^{\circ} \mathrm{C}$ for $30 \mathrm{~s}$. GAPDH was used as the housekeeping gene control. PCR was conducted in a $12.5-\mu \mathrm{l}$ reaction volume containing $2.5 \mu \mathrm{l}$ of $1 / 10$-diluted cDNA template and $10 \mu \mathrm{l}$ of a master mix $(0.25 \mu$ l of ROX, 6.25 $\mu \mathrm{l}$ of UDG, $0.5 \mu \mathrm{l}$ of $10 \mu \mathrm{M}$ primer mix and $3 \mu \mathrm{l}$ of nuclease-free $\mathrm{H}_{2} \mathrm{O}$ per reaction). A melting curve was performed to ensure that any product detected was specific to the desired amplicon. Fold changes were calculated after normalization to endogenous GAPDH using the comparative Ct method [52]. PCR primers used in this study were: IL-6 (forward) 5'-AATTCGGTACATCCTCGACGG-3', IL-6 (reverse) 5'-GGTTGTTTTCTGCCAGTGCC-3', GAPDH (forward) 5'-GAAACTGTGGCG TGATGG-3' and GAPDH (reverse) 5'-TCTAGAGGCATGCTGACTTC-3'.

\section{Western Immunoblotting}

$16 \mathrm{HBE} 14 \mathrm{o}^{-}$cells were seeded in $15 \times 30 \mathrm{~mm}$ plates (Sarstedt) at $2.8 \times 10^{5}$ cells $/ \mathrm{ml}$ and cultured to sub-confluence in MEM (with $10 \% \mathrm{FBS} / 2 \mathrm{mM} \mathrm{L}$-glutamine) at $37^{\circ} \mathrm{C}$ and $5 \% \mathrm{CO}_{2}$ for 2 days. On the day of treatment, medium was removed from the plates, and cells were washed with $1 \mathrm{ml}$ of serum-free MEM per plate. Cells were incubated with $1 \mathrm{ml}$ of serum-free MEM (containing $2 \mathrm{mM} \mathrm{L}$-glutamine) for $4 \mathrm{~h}$, followed by a medium change of $1 \mathrm{ml}$ of $2 \% \mathrm{FBS} / 2 \mathrm{mM}$ L-glutamine MEM and immediate treatment of cells. Prior to lysis, cells were washed with ice-cold PBS, containing $1 \mathrm{mM}$ sodium vanadate. Samples were solubilized on ice with NP-40 lysis buffer (1\% NP-40, 20 mM Tris-HCl, pH 8, 137 mM $\mathrm{NaCl}, 10 \%$ glycerol, $2 \mathrm{mM}$ EDTA) supplemented with protease and phosphatase inhibitor cocktails (Sigma-Aldrich), scraped and subsequently centrifuged. The protein concentration of cell lysates was quantified using the BCA Protein Assay Kit (Pierce, Rockford, Ill., USA). Lysates were denatured at $95^{\circ} \mathrm{C}$ for $10 \mathrm{~min}$ and were resolved on $12 \%$ SDS-PAGE, followed by subsequent transfer at $100 \mathrm{~V}$ for $1 \mathrm{~h}$ to immunoblot PVDF membranes (BioRad, Hercules, Calif., USA).

Membranes were probed with specific antibodies in TBST (20 $\mathrm{mM}$ Tris, $\mathrm{pH} 7.4,150 \mathrm{mM} \mathrm{NaCl}$ and $0.1 \%$ Tween-20) containing $5 \%$ skimmed milk powder (TBST/milk) or 5\% BSA (TBST/BSA), at dilutions and incubation times specified by the manufacturer. Incubation with an appropriate secondary antibody (HRP-conjugated goat anti-mouse or anti-rabbit antibody) was performed following the primary antibody incubation. Finally, the membranes were developed using the ECL chemiluminescence peroxidase substrate (Sigma-Aldrich), according to the manufacturer's instructions.
Pistolic/Cosseau/Li/Yu/Filewod/ Gellatly/Rehaume/Bowdish/Hancock 




Fig. 1. LL-37-induced cytokine (a)/chemokine (b) release from $16 \mathrm{HBE}_{14 \mathrm{o}^{-}}$cells. Confluent $16 \mathrm{HBE} 14 \mathrm{o}^{-}$cell monolayers were exposed for $6 \mathrm{~h}$ to $50 \mu \mathrm{g} / \mathrm{ml} \mathrm{LL}-37$ and $100 \mathrm{ng} / \mathrm{ml} \mathrm{LPS} \mathrm{(a)} \mathrm{or} 50 \mu \mathrm{g} / \mathrm{ml}$ LL-37 and $10 \mathrm{ng} / \mathrm{ml}$ of IL-1 $\beta$ (b). Cytokine/chemokine release in

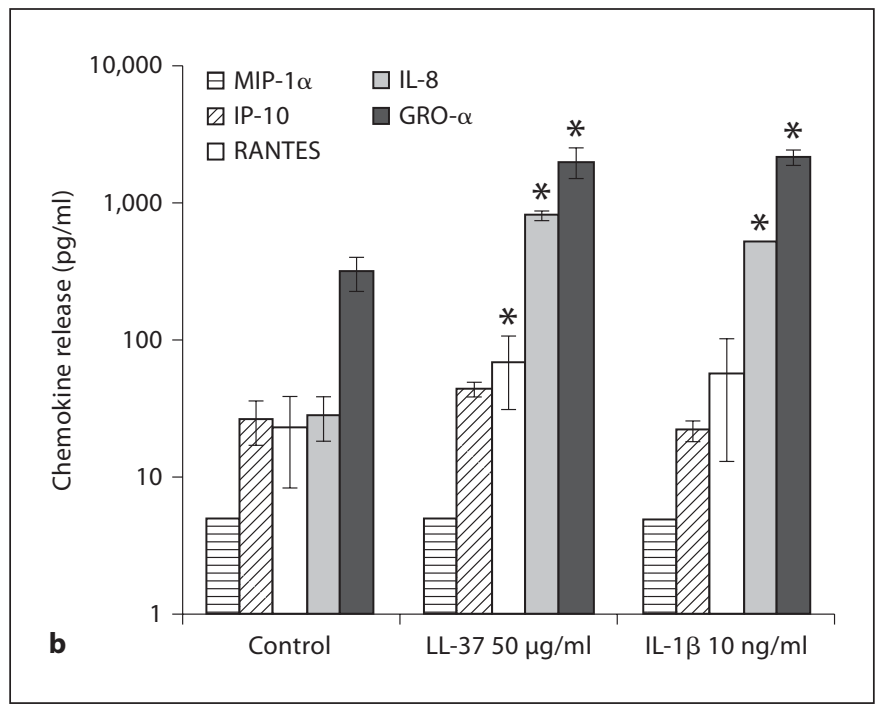

cell culture supernatants was determined via ELISA. Results are expressed as mean values of cytokine/chemokine produced ( $\mathrm{Y}$ scale-log scale) $\pm \mathrm{SD}$ of three independent experiments $\left({ }^{*} \mathrm{p}<\right.$ 0.05 vs. untreated controls).

\section{Nuclear Protein Isolation}

For nuclear extraction experiments, $16 \mathrm{HBE} 14 \mathrm{o}^{-}$cells were seeded, cultured and treated as described above. After appropriate incubation, cells were rinsed with PBS and incubated with 0.5 $\mathrm{ml}$ Versene (Life Technologies Invitrogen) per plate for 5-10 min at $37^{\circ} \mathrm{C}$ to promote cell detachment from the plate. Cells were centrifuged at $3,000 \mathrm{~g}$ for $3 \mathrm{~min}$ at $4^{\circ} \mathrm{C}$ and were subsequently washed with ice-cold PBS and re-centrifuged. Nuclear and cytoplasmic extracts were isolated using the NE-PER Nuclear and Cytoplasmic Extraction Reagents Kit (Pierce) according to the manufacturer's instructions. The extracts were stored in aliquots at $-80^{\circ} \mathrm{C}$ until further use. Protein concentrations of the samples were determined by the BCA assay (Pierce). Nuclear extracts (15 $\mu \mathrm{g}$ ) were denatured for $5 \mathrm{~min}$ at $95^{\circ} \mathrm{C}$, resolved by $7.5 \% \mathrm{SDS}$ PAGE and transferred at $100 \mathrm{~V}$ for $1 \mathrm{~h}$ to Immunoblot PVDF membranes (Bio-Rad).

\section{TUNEL Assay}

$16 \mathrm{HBE}_{14 \mathrm{o}^{-}}$cells were seeded in 8 -Chamber Slide Culture Chambers (VWR International, Mississauga, Ont., USA) at $2 \times$ $10^{4}$ cells/chamber in $10 \% \mathrm{FBS} / 2 \mathrm{mM}$ L-glutamine MEM and were cultured for 2 days. On the day of the assay, complete media were replaced with $2 \%$ FBS media and cells were rested for $1 \mathrm{~h}$. Cells were treated with 30 or $50 \mu \mathrm{g} / \mathrm{ml}$ of LL-37, hydrogen peroxide at $300 \mu \mathrm{M}$ or left untreated for $6 \mathrm{~h}$. After treatment incubations, cells were stained and processed using the DeadEnd Fluorometric TUNEL System (Promega), according to manufacturer's instructions (adherent cell instructions). Coverslips were mounted onto slides using Vectashield containing DAPI (Vector Laboratories) and viewed using a Nikon Eclipse TE2000-S fluorescence microscope.
Statistical Analysis

Student's t test was performed to determine the statistical significance of results, with $p \leq 0.05$ being considered statistically significant, with the exception of figure $4 c$, where ANOVA was done (GraphPad Prism 4). Values shown are expressed as means $\pm \mathrm{SD}$ as indicated in the Results section and figure legends.

\section{Results}

\section{LL-37-Stimulated Release of IL-6, GRO- $\alpha$ and IL-8 from Bronchial Epithelial Cells}

Several studies have addressed the LL-37-mediated effect on cytokine/chemokine release and its regulation in leucocytes and keratinocytes [22, 30, 39-42, 45]. In airway epithelial cells, however, LL-37 has been shown only to induce IL-8, via EGFR and MAPK regulation [39, 41]. Various cytokines and chemokines, including IL-8, are important effector molecules of lung innate immunity which affect inflammation, and infection development and resolution through a cornucopia of functions [2]. These small molecules act to balance and regulate infiltration of specific effector cell populations to the affected site, regulate induction of local chemical defence molecules, and govern tissue remodeling and wound healing. Therefore, we aimed to examine if LL-37 would act to induce other cytokines/chemokines in addition to IL- 8 in airway epithelial cells. 


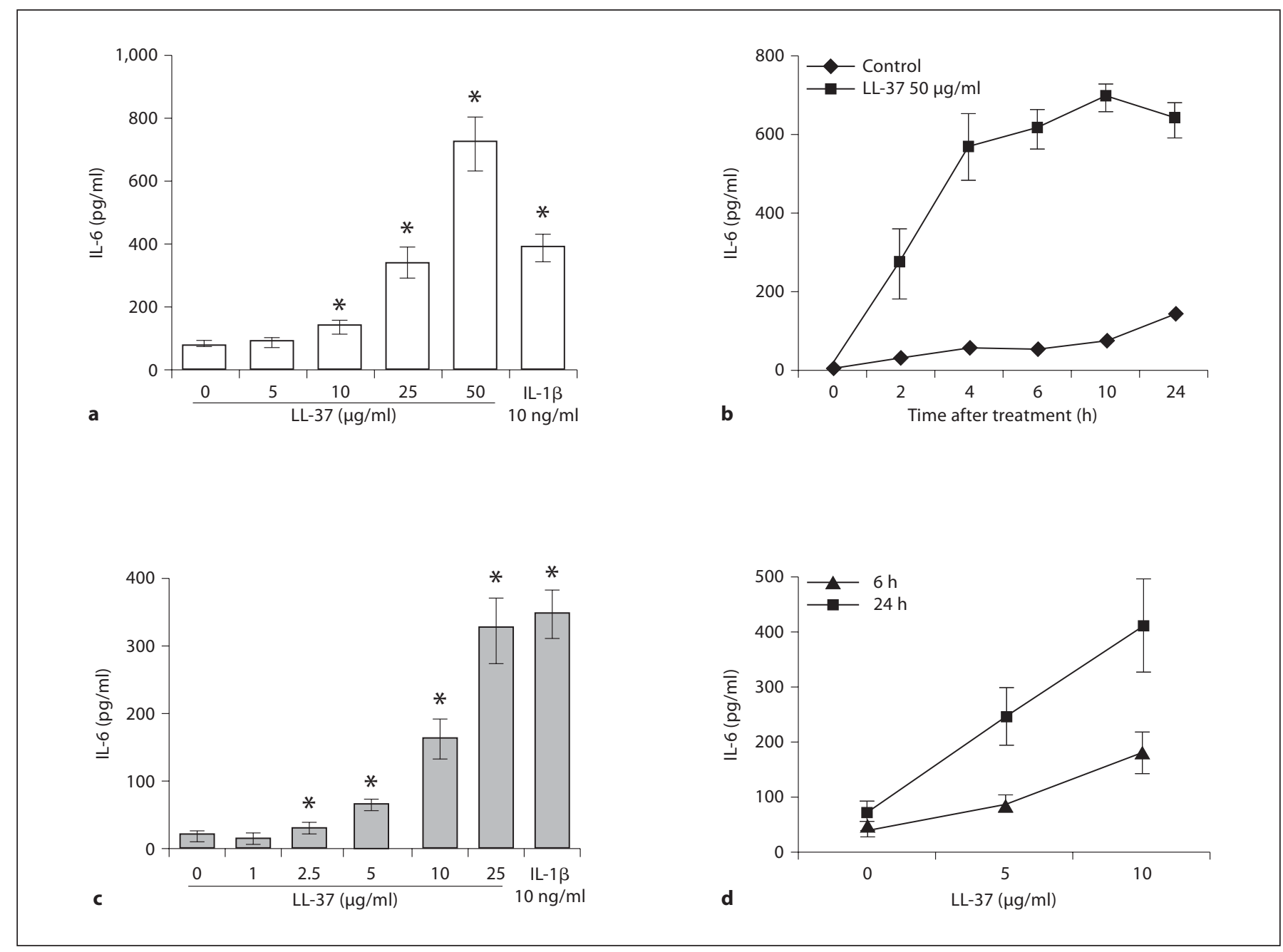

Fig. 2. LL-37 induces IL- 6 release from the $16 \mathrm{HBE} 14 \mathrm{o}^{-}$bronchial epithelial cell line and primary NHBE cells in a dose- and timedependent manner. Confluent $16 \mathrm{HBE} 14 \mathrm{o}^{-}$monolayers were treated with LL-37 at 5, 10, 25 and $50 \mu \mathrm{g} / \mathrm{ml}$ concentrations, or IL- $1 \beta$ at $10 \mathrm{ng} / \mathrm{ml}$ for $6 \mathrm{~h} \mathrm{(a),} \mathrm{or} 50 \mu \mathrm{g} / \mathrm{ml}$ of LL-37 for 2, 4, 6, 10 and 24 $\mathrm{h}(\mathbf{b})$. Confluent primary NHBE monolayers were treated with 1 ,
2.5, 5, 10, 25 and $50 \mu \mathrm{g} / \mathrm{ml}$ of LL-37 or IL-1 $\beta$ for $6 \mathrm{~h}$ (c), or 5 and $10 \mu \mathrm{g} / \mathrm{ml}$ of LL-37 for 6 or $24 \mathrm{~h}$ (d). IL- 6 release in culture supernatants was determined by ELISA. Results are expressed as means $\pm \mathrm{SD}$ of three independent experiments $\left({ }^{*} \mathrm{p}<0.05\right.$ vs. untreated controls).
To determine which cytokines and/or chemokines were induced, $16 \mathrm{HBE} 14 \mathrm{o}^{-}$cells were stimulated with LL37 at $50 \mu \mathrm{g} / \mathrm{ml}, 100 \mathrm{ng} / \mathrm{ml}$ of LPS or $10 \mathrm{ng} / \mathrm{ml}$ of IL- $1 \beta$ for $6 \mathrm{~h}$. Cytokines/chemokines released into the cell culture supernatants were measured by ELISA. LL-37 induced a significant amount of the cytokine IL- $6(\mathrm{p}<0.05)$, without inducing detectable IL-1 $\beta$, TNF- $\alpha$ or IL-10 from $16 \mathrm{HBE}_{14 \mathrm{o}^{-}}$cells (fig. 1a). With respect to chemokine release, LL-37 significantly induced the release of CCL-5/ RANTES, CXCL-8/IL- 8 and CXCL-1/GRO- $\alpha$, while no significant induction of CCL3/MIP-1 $\alpha$ or CXCL-10/IP-10 was observed (fig. 1b). Similar to the $16 \mathrm{HBE} 14 \mathrm{o}^{-}$cell re- sults, primary NHBE cells had increased IL-6, IL-8 and Gro- $\alpha$ protein release $(\mathrm{p}<0.05)$, but without significant RANTES induction (fig. 2, and data not shown). LL-37induced cytokine/chemokine release was a specific peptide-mediated response and not just a reflection of a general inflammatory response, e.g. due to either contaminating endotoxin or a secondary effect of autocrine stimulation with IL-1 $\beta / \mathrm{TNF}-\alpha$, since the pattern of stimulation differed from that with these agents (fig. 1a). Similar results were observed in both primary cells and a bronchial cell line, thereby corroborating the physiological relevance of these results. 


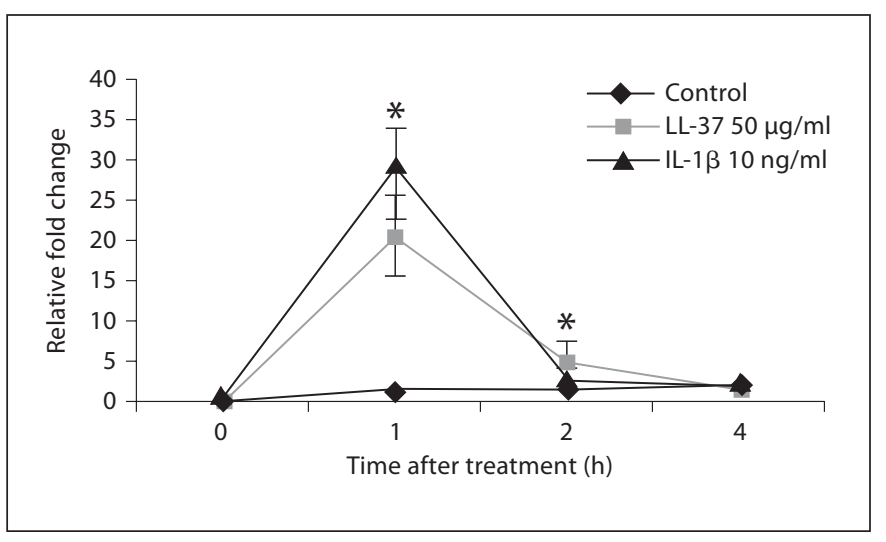

Fig. 3. LL-37 enhances IL- 6 gene expression in $16 \mathrm{HBE} 14 \mathrm{o}^{-}$cells. $16 \mathrm{HBE}_{14 \mathrm{o}^{-}}$cells were exposed to LL-37 at $50 \mu \mathrm{g} / \mathrm{ml}$, or IL-1 $\beta$ at $10 \mathrm{ng} / \mathrm{ml}$ for 1,2 and $4 \mathrm{~h}$. Transcriptional regulation was assessed via quantitative RT-PCR. Fold changes (y-axis) were normalized to GAPDH and are relative to the gene expression in unstimulated cells (normalized to 1) using the comparative Ct method (refer to Materials and Methods for details). Results are expressed as means $\pm \mathrm{SD}$ of three independent experiments $\left({ }^{*} \mathrm{p}<0.05 \mathrm{vs}\right.$. the respective untreated control at a given time point).

\section{LL-37-Stimulated IL-6 Cytokine Release}

from Bronchial Epithelial Cells in a Dose- and

Time-Dependent Manner

To gain further insights into the effects of LL-37 on cytokine/chemokine production, we exposed airway epithelial cells to a range of LL-37 concentrations over various time frames, and focused on the regulation of IL- 6 as it appeared the most interesting due to the pleiotropic nature of this cytokine.

As shown in figure 2, LL-37 induced IL-6 release from both $16 \mathrm{HBE}_{14 \mathrm{o}^{-}}$cells and primary NHBE cells in a doseand time-dependent manner. A statistically significantly enhanced IL- 6 production and release was seen with as little as $2.5-10 \mu \mathrm{g} / \mathrm{ml}$ of LL-37 ( $\mathrm{p}<0.05$; fig. 2). In $16 \mathrm{HBE}_{14 \mathrm{o}^{-}}$cells, a more prominent increase was observed with 25 and $50 \mu \mathrm{g} / \mathrm{ml}$ of the peptide with 4 - and 9-fold up-regulation of IL- 6 production and release, respectively (fig. 2a). In these cells, LL-37 induced IL-6 release at the earliest time point evaluated, while the peak of accumulation was observed between 6 and $10 \mathrm{~h}$ (fig. 2b).

Comparable results were obtained with primary NHBE cells (fig. 2c, d), demonstrating the physiological relevance of these results. Primary NHBE cells were even more sensitive to LL-37 stimulation with significant IL-6 release upon stimulation with as low as $2.5 \mu \mathrm{g} / \mathrm{ml}$ of LL37 ( $\mathrm{p}<0.05$; fig. 2c). As described for the $16 \mathrm{HBE} 14 \mathrm{o}^{-}$cell line, LL-37-stimulated primary cells released IL-6 in a time-dependent manner (fig. $2 \mathrm{~d}$ ), with significant accumulation of the cytokine as early as $6 \mathrm{~h}$ after stimulation, and continuing up until $24 \mathrm{~h}$ after stimulation.

To evaluate the effect of LL-37 on IL- 6 regulation at the transcriptional level, $16 \mathrm{HBE} 14 \mathrm{o}^{-}$cells were treated with $50 \mu \mathrm{g} / \mathrm{ml}$ of LL-37 or $10 \mathrm{ng} / \mathrm{ml}$ of IL-1 $\beta$ over a time course of 1, 2 and $4 \mathrm{~h}$. Total RNA was extracted from treated samples, and the IL- 6 transcriptional profile was subsequently assessed by quantitative PCR (fig. 3). LL-37 induced the up-regulation of IL- 6 gene expression in a time-dependent manner in $16 \mathrm{HBE}^{-14 \mathrm{o}^{-}}$cells. As shown in figure 3, $50 \mu \mathrm{g} / \mathrm{ml}$ of LL-37 (the dose that induced maximal protein release) increased IL- 6 transcription 20 \pm 4.9 times within $1 \mathrm{~h}$ of peptide addition. This up-regulation decreased to $5.5 \pm 1.4$ times at $2 \mathrm{~h}(\mathrm{p}<0.05)$, and ultimately approached near control levels $4 \mathrm{~h}$ after stimulation ( $p>0.05)$. A similar pattern of transcriptional upregulation was observed with $10 \mathrm{ng} / \mathrm{ml}$ of the positive control IL-1 $\beta$, which induced peak transcription at $1 \mathrm{~h}$ $(28 \pm 5.6$ fold, $\mathrm{p}<0.05)$ and a subsequent decrease 2 and $4 \mathrm{~h}$ after stimulation to $2.37 \pm 1.26$ and $1.98 \pm 0.78$ fold, respectively $(\mathrm{p}>0.05)$.

\section{NF- $\kappa B$ Signaling Is a Major Regulator of \\ LL-37-Induced IL-6 in 16HBE14o- Cells}

As shown above, LL-37-mediated induction of IL-6 in bronchial epithelial cells stemmed from transcriptional up-regulation (fig. 3). Literature indicates that IL-6 transcription is mediated via activation of transcription factors NF- $\kappa \mathrm{B}, \mathrm{CREB}$, activator protein-1 (AP-1) and nuclear factor IL-6 (NF-IL-6) [53, 54]. In particular, studies on bronchial epithelial cells show that IL-6 is NF- $\kappa \mathrm{B}$ regulated [55-57], thus making this transcription factor an excellent signaling regulator candidate of LL-37-mediated IL- 6 production. To examine if NF- $\kappa \mathrm{B}$ activation was involved in IL-6 production in LL-37-exposed $16 \mathrm{HBE} 14 \mathrm{o}^{-}$ cells, we utilized two chemical inhibitors of NF- $\kappa B$ activation, Bay11-7085 and parthenolide (fig. 4a, b). $16 \mathrm{HBE} 14 \mathrm{o}^{-}$cells were incubated with Bay11-7085 or parthenolide at $10 \mu \mathrm{M}$ for $1 \mathrm{~h}$ prior to stimulation with LL-37 (30 or $50 \mu \mathrm{g} / \mathrm{ml}$ ) or IL-1 $\beta(10 \mathrm{ng} / \mathrm{ml})$ for $6 \mathrm{~h}$. As expected, both inhibitors abrogated all IL- 6 induced by both LL-37 concentrations tested, as well as the IL-1 $\beta$ treatment (fig. $4 a, b)$. Furthermore, to examine other signaling regulation of LL-37-mediated IL-6 production, we used the following inhibitors: AG1478 (EGFR inhibitor), PD98059 (MEK/ERK inhibitor), SB203580 (p38 inhibitor), SP600125 (JNK inhibitor) and pertussis toxin (G-protein-coupled receptor inhibitor; fig. 4c). Similarly to NF- 


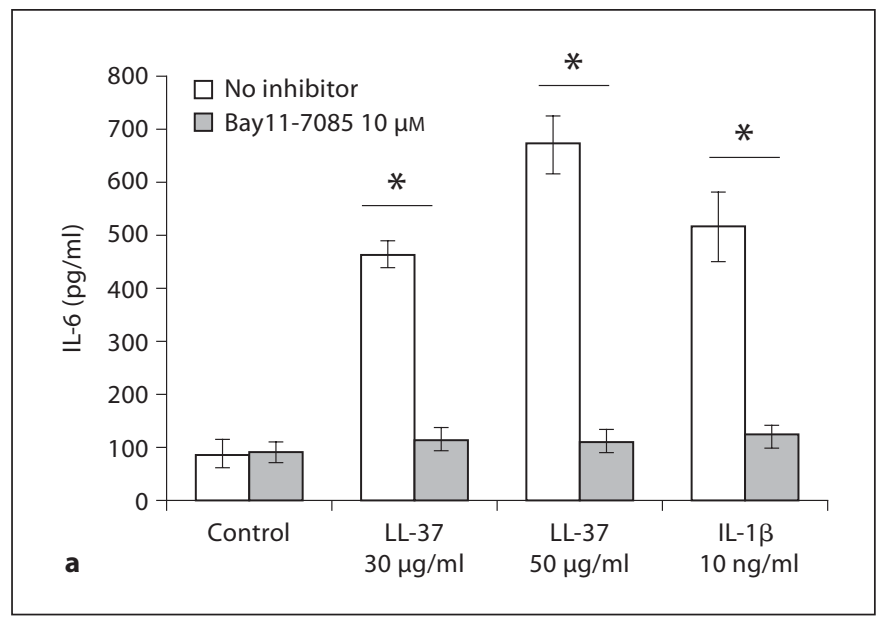

Fig. 4. LL-37-induced IL-6 release in $16 \mathrm{HBE} 14 \mathrm{o}^{-}$cells is robustly regulated by NF- $\kappa \mathrm{B}$ signaling. Confluent $16 \mathrm{HBE} 14 \mathrm{o}^{-}$monolayers were treated with Bay 11-7085 (Iк-B $\alpha$ phosphorylation inhibitor) at $10 \mu \mathrm{M}(\mathbf{a})$, or parthenolide (NF- $\kappa \mathrm{B}$ inhibitor) at $10 \mu \mathrm{M}$ for $1 \mathrm{~h}$ (b), prior to stimulation with LL-37 at 30 and $50 \mu \mathrm{g} / \mathrm{ml}$, or IL-1 $\beta$ at $10 \mathrm{ng} / \mathrm{ml}$ for $6 \mathrm{~h}$. c Confluent $16 \mathrm{HBE} 14 \mathrm{o}^{-}$monolayers were pretreated with AG1478 $1 \mu \mathrm{M}$ (EGFR inhibitor), PD98059 $12.5 \mu \mathrm{M}$ (MEK/ERK inhibitor), SB203580 $12.5 \mu \mathrm{M}$ (p38 inhibitor), SP600125 $5 \mu \mathrm{M}$ (JNK inhibitor) or pertussis toxin (PTX) $100 \mathrm{ng} /$ $\mathrm{ml}$ for $1 \mathrm{~h}$ prior to stimulation with $30 \mu \mathrm{g} / \mathrm{ml} \mathrm{LL}-37$ for $6 \mathrm{~h}$. Supernatants were assayed for IL- 6 release by ELISA. Results are expressed as averages \pm SEM of three independent experiments $\left({ }^{*} \mathrm{p}<0.05\right.$ vs. the respective treatment without the inhibitor). c ANOVA ( ${ }^{*} p<0.05$ vs. the respective treatment without the inhibitor).

$\kappa \mathrm{B}$ inhibitor experiments, $16 \mathrm{HBE} 14 \mathrm{o}^{-}$cells were pre-incubated with inhibitors for $1 \mathrm{~h}$ prior to stimulation with $30 \mu \mathrm{g} / \mathrm{ml}$ of LL-37 for $6 \mathrm{~h}$. As shown in figure $4 \mathrm{c}$, none of the tested inhibitors showed the level of inhibition observed with either of the NF- $\kappa B$ inhibitors.

To further corroborate that the NF- $\kappa \mathrm{B}$ pathway was implicated in LL-37-mediated responses in bronchial epithelial cells, we investigated the activation of this pathway more directly. Specifically, $16 \mathrm{HBE} 14 \mathrm{o}^{-}$cells were treated with $50 \mu \mathrm{g} / \mathrm{ml}$ of LL-37, or $10 \mathrm{ng} / \mathrm{ml}$ of IL-1 $\beta$ (as a positive control), over a time course of 15,30 and 60 min, while phosphorylation and degradation levels of Iк$\mathrm{B} \alpha$ were examined by Western blotting. LL-37 induced Iк-B $\alpha$ phosphorylation within 15 min of stimulation (fig. 5a), and this effect was confirmed by the LL-37-induced degradation of total Iк-B $\alpha$ (fig. 5b). In addition to examining I $\mathrm{I}-\mathrm{B} \alpha$ regulation, a more direct approach was taken, and nuclear translocation of p50 and p 65 NF- $\kappa \mathrm{B}$ subunits was examined upon $16 \mathrm{HBE} 14 \mathrm{o}^{-}$cell stimulation
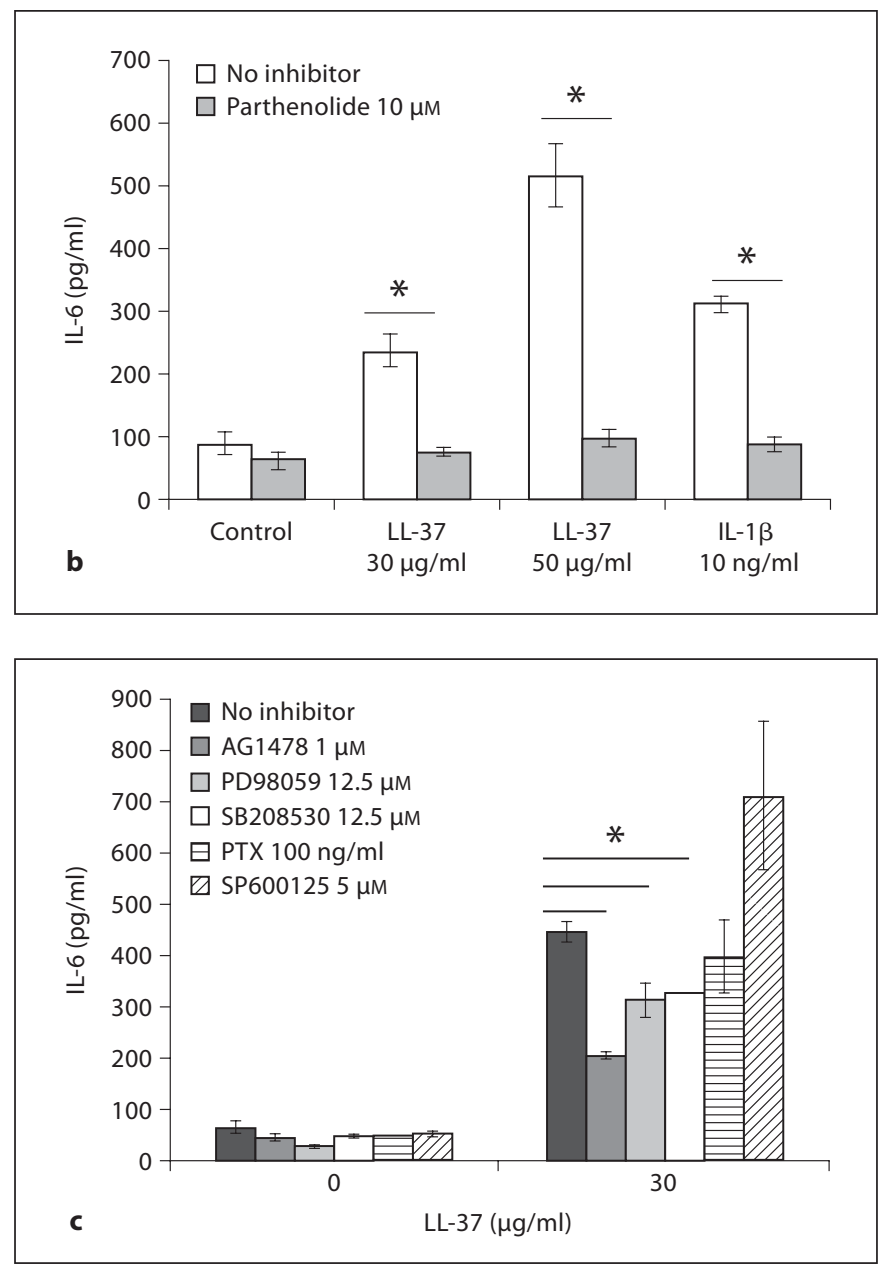

with LL-37 at 30 and $50 \mu \mathrm{g} / \mathrm{ml}$. Both peptide concentrations were able to induce nuclear translocation of both p50 and p65 NF- $\kappa$ B subunits, as did the flagellin-positive control at $1 \mu \mathrm{g} / \mathrm{ml}$ (fig. 6), thus providing more direct evidence of peptide-induced NF- $\mathrm{B}$ activation. Therefore, in addition to demonstrating that LL-37 stimulation can lead to NF-кB pathway activation (fig. 6), it was established that this signaling pathway is a major regulator of LL-37-induced IL-6 production in bronchial epithelial cells (fig. 4).

\section{LL-37 Increased Flagellin-Induced IL-6 Release from Bronchial Epithelial Cells}

LL-37 has been shown to modulate TLR responses in several cell systems. In monocytes/macrophages it has been demonstrated to delicately balance and selectively modify transcriptional responses to LPS/TLR4 signaling [27], while in DCs it interferes with TLR ligand-mediated activation through cytokine inhibition and alteration of 


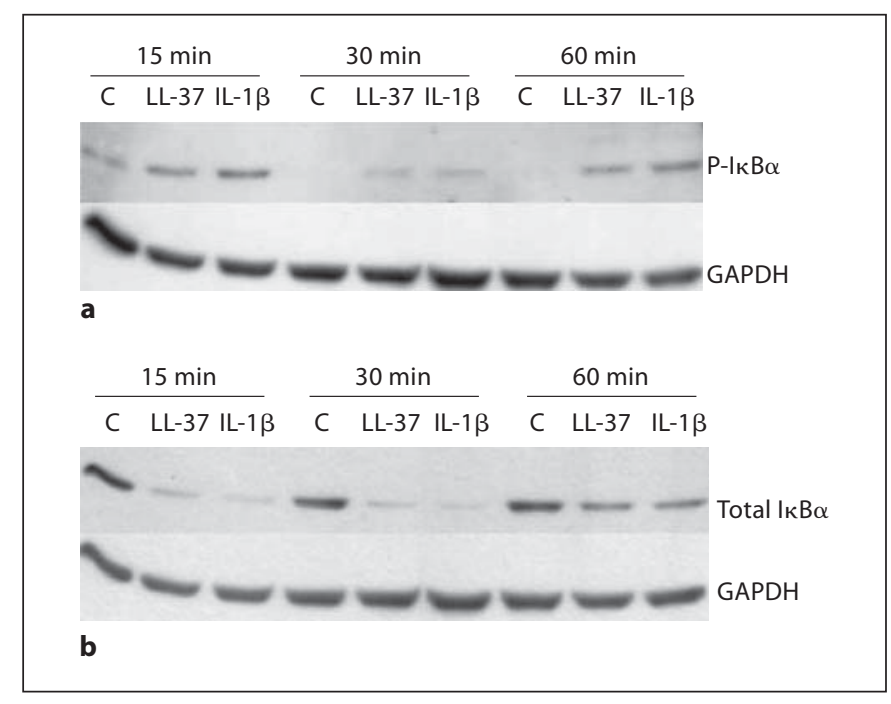

Fig. 5. LL-37 induces I $\mathrm{I}-\mathrm{B} \alpha$ phosphorylation (a) and total I $\mathrm{I}-\mathrm{B} \alpha$ degradation (b) in $16 \mathrm{HBE} 14 \mathrm{o}^{-}$cells. $16 \mathrm{HBE} 14 \mathrm{o}^{-}$cells were treated with $50 \mu \mathrm{g} / \mathrm{ml} \mathrm{LL}-37,10 \mathrm{ng} / \mathrm{ml}$ IL-1 $\beta$, or were left untreated (control, C), over a time course of 15,30 and $60 \mathrm{~min}$. Whole cell protein lysates were prepared and analysed by SDS-PAGE and immunoblotting. The housekeeping protein GAPDH was assessed as a loading control. Results are from one experiment for each panel, representative of three experiments.

surface marker and receptor expression [38]. While many studies indicate that bronchial epithelial cells respond poorly to LPS stimulation (also observed here, fig. 1a) due to low expression of the LPS receptor TLR4 and/or the lack of certain accessory molecules required for TLR4 pathway induction [58-60], TLR5 expression and the role of the TLR5 signaling pathway in pathogen recognition (via flagellin) in the lung has been well described $[61,62]$. Therefore, the effect of LL-37 on flagellin-mediated cytokine release was examined.

To determine whether LL-37 would have any effect on flagellin-mediated cytokine release in airway epithelial cells, $16 \mathrm{HBE} 14 \mathrm{o}^{-}$cells were treated with a range of LL-37 doses and/or flagellin at $1 \mu \mathrm{g} / \mathrm{ml}$ for $6 \mathrm{~h}$. Cell culture supernatants were tested for IL- 6 release by ELISA. Over a range of concentrations, LL-37 significantly $(\mathrm{p}<0.05)$ enhanced flagellin-induced IL- 6 production and release (fig. $7 \mathrm{a}$ ) in $16 \mathrm{HBE} 14 \mathrm{o}^{-}$cells. In order to distinguish between additive and synergistic induction of IL- 6 mediated by LL-37 and flagellin, a comparative statistical analysis has been done on summed values of individual peptide and flagellin stimulations versus the values obtained from co-stimulated samples (data not shown). Only the 30 and $50 \mu \mathrm{g} / \mathrm{ml} \mathrm{LL}-37$ + flagellin co-stimula-

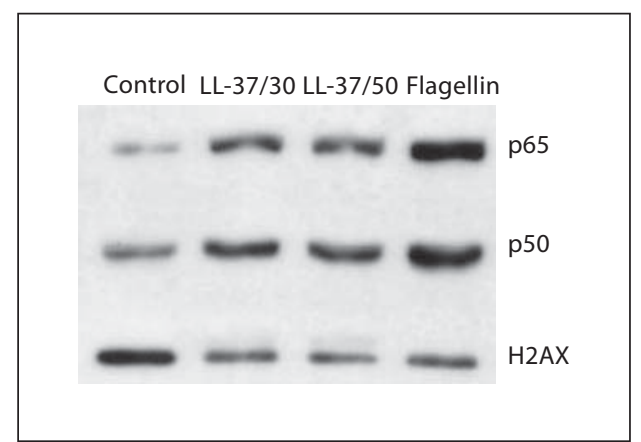

Fig. 6. LL-37 induces $\mathrm{p} 50$ and $\mathrm{p} 65 \mathrm{NF}-\kappa \mathrm{B}$ subunit translocation into the nucleus in $16 \mathrm{HBE}_{14 \mathrm{o}^{-}}$cells. $16 \mathrm{HBE} 14 \mathrm{o}^{-}$cells were treated with 30 or $50 \mu \mathrm{g} / \mathrm{ml} \mathrm{LL}-37$ alone, $1 \mu \mathrm{g} / \mathrm{ml}$ flagellin alone, or were left untreated (control), for $30 \mathrm{~min}$. Nuclear extracts were isolated and analyzed by SDS-PAGE and immunoblotting. Immunoblots were probed for $\mathrm{p} 50$ and $\mathrm{p} 65 \mathrm{NF}-\mathrm{\kappa B}$ subunits, as well as H2AX histone antibody as a loading control for nuclear extracts. Results shown are from a representative experiment (out of three).

tion treatments synergistically increased IL- 6 release in $16 \mathrm{HBE}_{14 \mathrm{o}^{-}}$cells ( $\mathrm{p}<0.05$, Student's t test), while the other peptide doses mediated an additive effect. Similar peptide and flagellin augmentation of IL- 6 release $(\mathrm{p}<0.05)$ was observed in primary NHBE cells (fig. 7b), even at very low LL-37 concentrations $(<5 \mu \mathrm{g} / \mathrm{ml})$. In primary HBE cells, only LL-37 at $3 \mu \mathrm{g} / \mathrm{ml}$ synergistically enhanced IL- 6 production in flagellin co-stimulated treatment $(\mathrm{p}<$ $0.05)$. These results indicate that LL-37 can act as a costimulatory molecule to increase TLR5-mediated cytokine release in bronchial epithelial cells. The signaling regulation of this cooperative effect of LL-37 and flagellin on IL-6 induction was tested in primary NHBE cells with the use of chemical inhibitors. Primary NHBE cells were pretreated with $20 \mu \mathrm{M}$ of LY294002, $15 \mu \mathrm{M}$ of PD98059 or $15 \mu \mathrm{M}$ of SB203580 for $1 \mathrm{~h}$, and were subsequently treated with LL-37 alone at $3 \mu \mathrm{g} / \mathrm{ml}$, flagellin alone at 500 $\mathrm{ng} / \mathrm{ml}$, or with both the peptide and flagellin simultaneously for $6 \mathrm{~h}$. Cell culture supernatants were tested for IL- 6 release by ELISA. As shown in figure 8, PI3K (fig. 8a) and p38 (fig. $8 \mathrm{~b}$ ) signaling pathways regulate IL- 6 production mediated by co-stimulation of LL-37 and flagellin and each of the treatment alone, while no significant effect was observed with ERK1/2 inhibition.

Previous reports showed that LL-37 at concentrations $>30 \mu \mathrm{g} / \mathrm{ml}$ in airway epithelial cell lines (no FBS), and $>10 \mu \mathrm{g} / \mathrm{ml}$ in primary NHBE cells (10\% FBS) induces concentration-dependent apoptosis after $\sim 24 \mathrm{~h}$ of stimulation $[22,23]$. As a control experiment we treated 


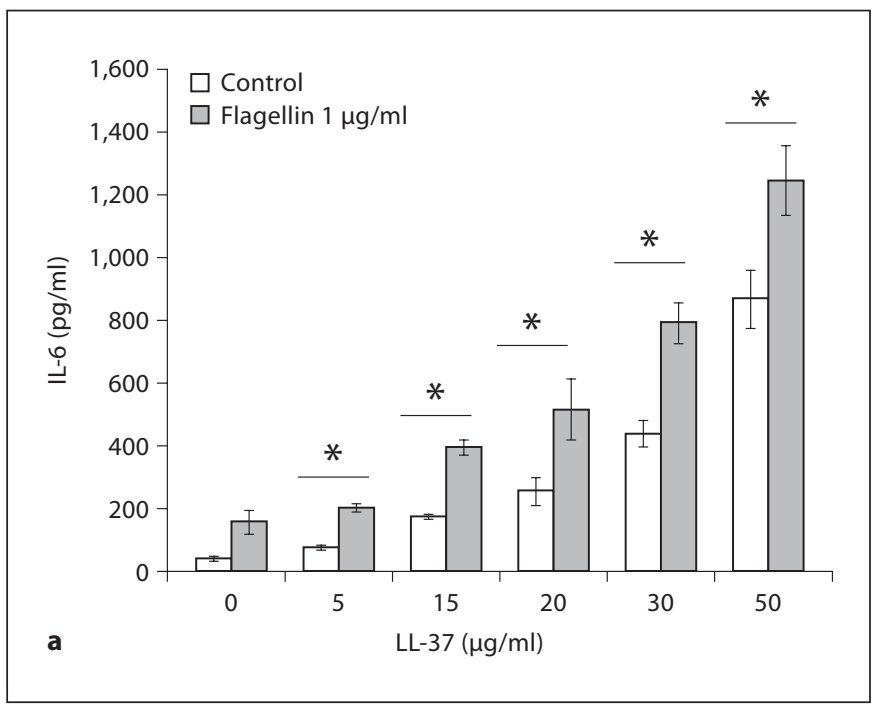

Fig. 7. LL-37 increased flagellin-induced IL-6 release in $16 \mathrm{HBE} 14 \mathrm{o}^{-}$and primary NHBE cells. a Confluent $16 \mathrm{HBE}^{-} \mathrm{oo}^{-}$ cells were treated with LL-37 at 5, 15, 20, 30 and $50 \mu \mathrm{g} / \mathrm{ml}$ alone, flagellin at $1 \mu \mathrm{g} / \mathrm{ml}$ alone, or flagellin and LL-37 (at 5, 15, 20, 30 and $50 \mu \mathrm{g} / \mathrm{ml}$ ) in combination, or were left untreated (control) for $6 \mathrm{~h}$. b Confluent pNHBE cells were treated with 1 or $3 \mu \mathrm{g} / \mathrm{ml}$ of

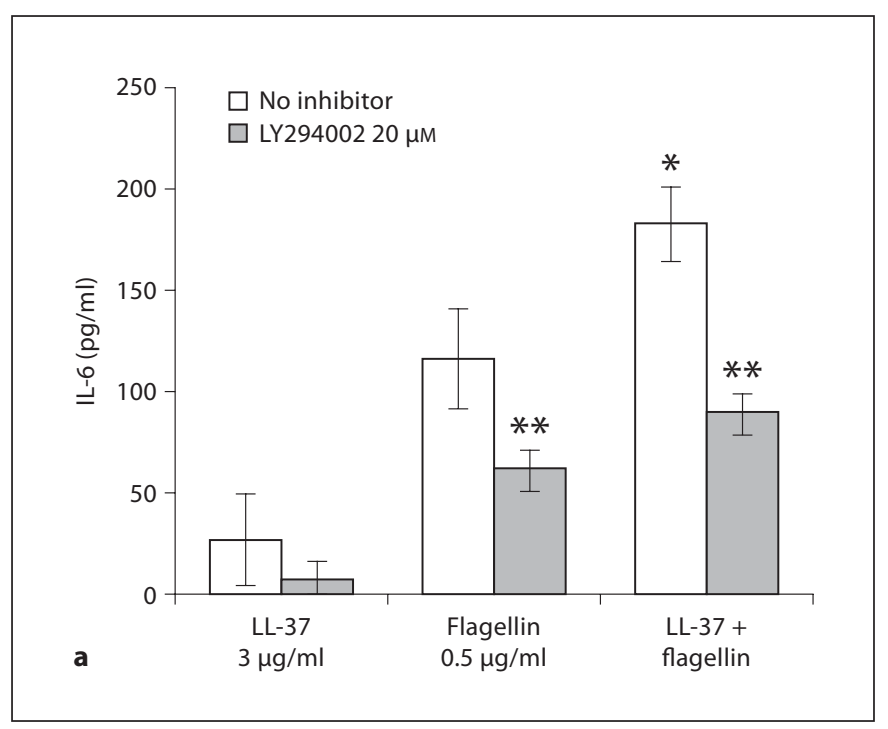

Fig. 8. LL-37 increased flagellin-induced IL-6 release in primary NHBE cells is regulated by PI3K and p38 signaling. Confluent primary NHBE cells were pretreated with PI3K inhibitor LY294002 at $20 \mu \mathrm{M}$ (a) or ERK1/2 inhibitor PD98059 at $15 \mu \mathrm{M}$ or p38 inhibitor SB203580 at $15 \mu \mathrm{M}$ (b) and were treated for $1 \mathrm{~h}$ with $3 \mu \mathrm{g} / \mathrm{ml}$ of LL-37 alone, $500 \mathrm{ng} / \mathrm{ml}$ flagellin alone, flagellin and

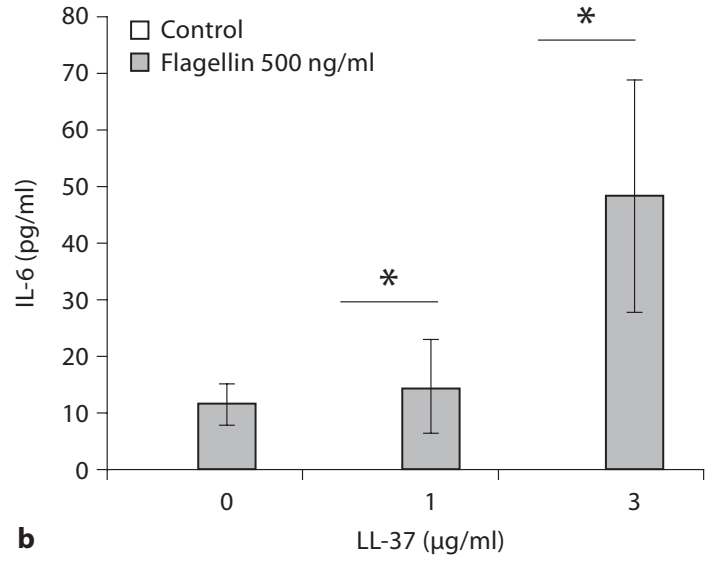

LL-37 alone, $500 \mathrm{ng} / \mathrm{ml}$ flagellin alone, flagellin and LL-37 combined ( 1 and $3 \mu \mathrm{g} / \mathrm{ml}$ ), or were left untreated (control) for $6 \mathrm{~h}$. IL6 release in culture supernatants was determined via ELISA. Results are expressed as means \pm SD of three independent experiments ( ${ }^{*} \mathrm{p}<0.05$ vs. LL-37 alone).

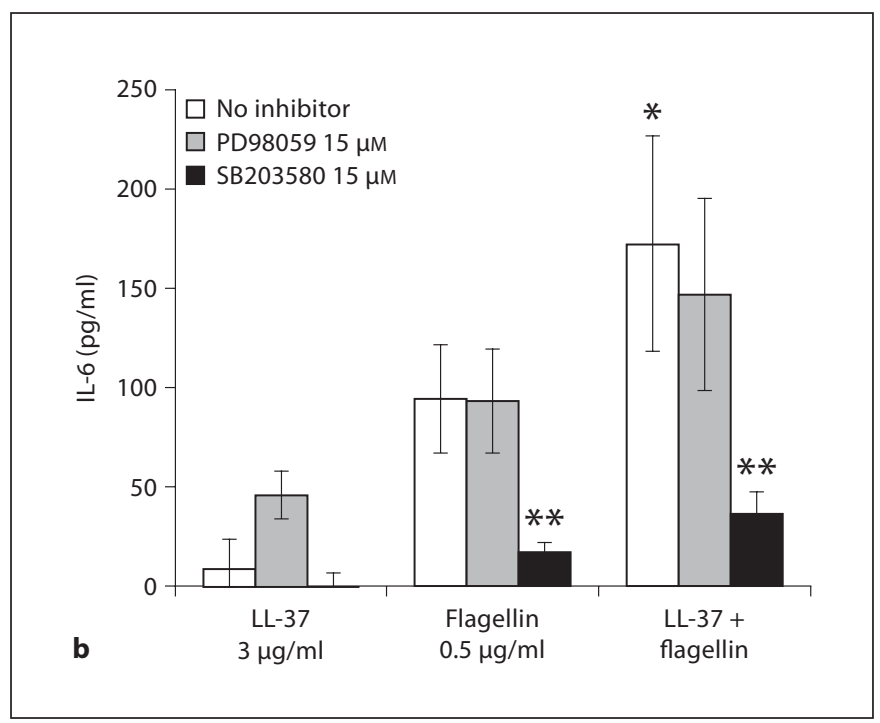

LL-37 combined ( $3 \mu \mathrm{g} / \mathrm{ml})$, or were left untreated (control: no inhibitor) for 6 h. IL- 6 release in culture supernatants was determined via ELISA. Results are expressed as means \pm SD of three independent experiments $\left({ }^{*} \mathrm{p}<0.05\right.$ vs. flagellin alone, ${ }^{* *} \mathrm{p}<$ 0.05 vs. respective treatment without inhibitor). 


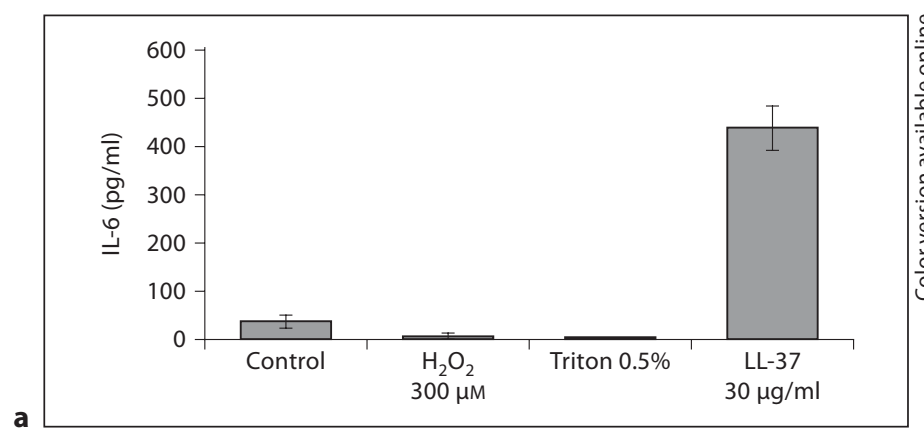

b
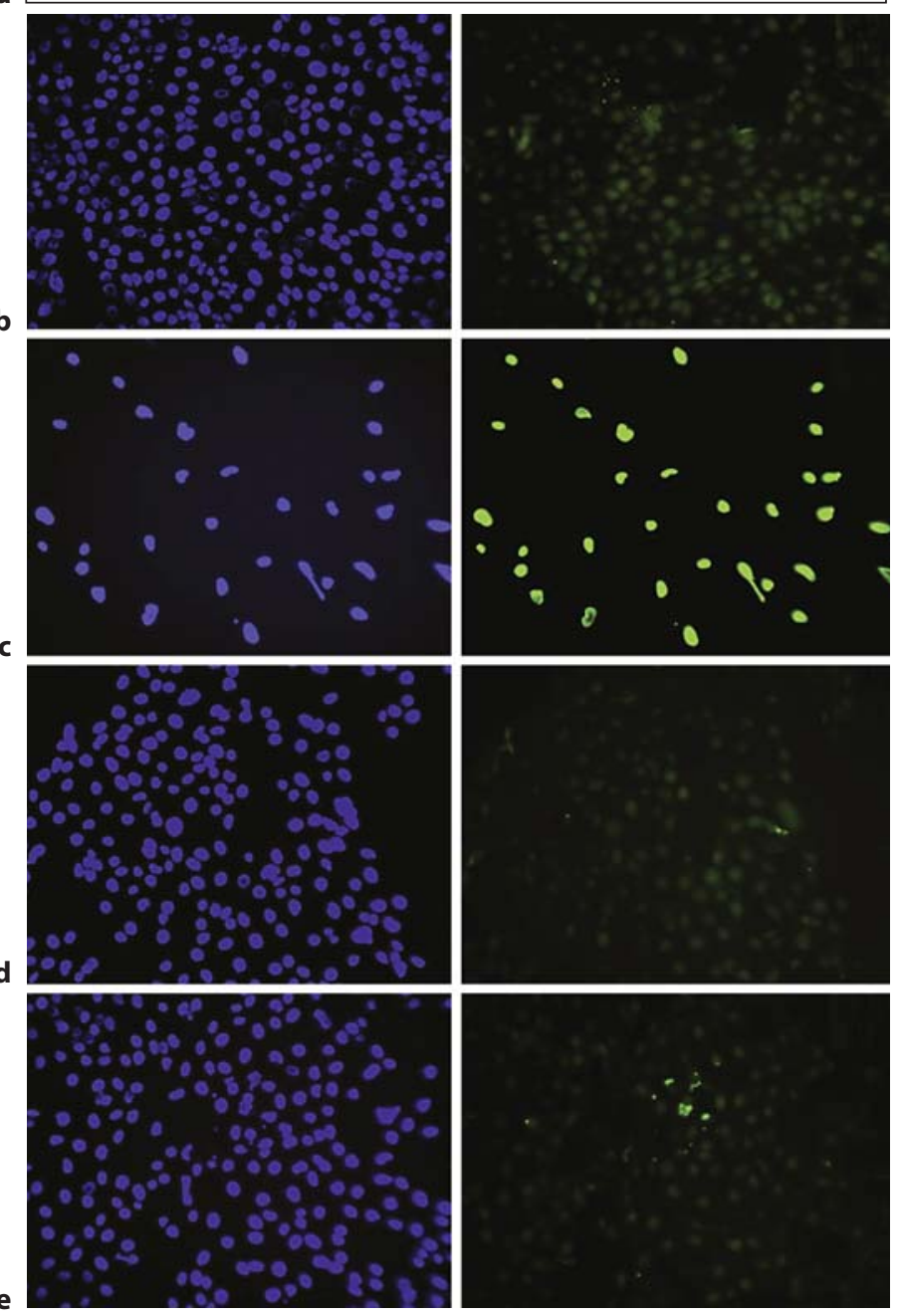

Fig. 9. IL-6 induction in $16 \mathrm{HBE}^{-14 \mathrm{o}^{-}}$cells and toxicity. a Confluent $16 \mathrm{HBE}_{14 \mathrm{o}^{-}}$cells were treated with $30 \mu \mathrm{g} / \mathrm{ml}$ of LL-37, $0.5 \%$ of Triton X-100 (necrosis inducer) and $300 \mu \mathrm{M}$ hydrogen peroxide (apoptosis inducer) for $6 \mathrm{~h}$. IL- 6 release in culture supernatants was determined by ELISA. Results are expressed as means \pm SD of three independent experiments. b Sub-confluent $16 \mathrm{HBE}^{-} \mathrm{bo}^{-}$ cells were left untreated (b), were treated with $300 \mu \mathrm{M} \mathrm{H} \mathrm{H}_{2} \mathrm{O}_{2}$ (apoptosis inducer; c), or 30 (d) or $50 \mu \mathrm{g} / \mathrm{ml}$ of LL-37 (e) for $6 \mathrm{~h}$. After treatment incubation, a TUNEL assay was performed. A single field of view out of three from a representative experiment (out of three) is shown for each treatment, with DAPI-stained cells (left) and TUNEL-positive cells (right).

LL-37 Activates NF-кB in Airway Epithelial Cells
$16 \mathrm{HBE} 14 \mathrm{o}^{-}$cells in media containing $2 \%$ FBS with $30 \mu \mathrm{g} /$ $\mathrm{ml}$ of LL-37, 0.5\% Triton X-100 (as a necrosis inducer) and $300 \mu \mathrm{M}$ hydrogen peroxide (as an apoptosis inducer) to show that the observed effect was due to specific peptide action. Unlike the positive control, hydrogen peroxide, LL-37 caused minor apoptosis as judged by TUNEL staining, even at $50 \mu \mathrm{g} / \mathrm{ml}$ (fig. 9b-e) $6 \mathrm{~h}$ after treatment. As shown in figure 9a, only LL-37 was able to induce a significant level of IL-6 release from airway epithelial cells.

\section{Discussion}

Substantial increases in the local concentration of host defence peptide LL-37, the only human cathelicidin, have been described during inflammation or infection of various sites including psoriatic lesions [11, 63], subcutaneous wounds [64], nasal secretions of patients with chronic rhinitis [65], cystic fibrosis, pulmonary sarcoidosis and COPD $[16-18,66]$. Host defence peptide LL-37 appears to be a potent modulator of immune response mediating multiple immunomodulatory effects. For example, it is capable of acting as an anti-inflammatory agent and neutralizing TLR-ligand-induced production of pro-inflammatory cytokines (TNF- $\alpha$, IL6 and IL-1 $\beta$ ) by monocytes/ macrophages and DCs $[27,38]$. In addition, LL-37 can directly affect pro-inflammatory responses by stimulating numerous cell types to produce chemokines, through which differential recruitment of various effector cells could affect the course and outcome of inflammation and infection $[30,39,43,67,68]$. Furthermore, LL-37 can synergize with other inflammatory mediators, such as GMCSF and IL-1 $\beta$, to mediate the induction of various chemokines [27, 39, 42]. LL-37 may also be involved in the regulation of homeostasis and integrity of various epithelial sites through modulation of cell proliferation and induction of wound healing $[30-33,69]$. To date the interaction of LL-37 with epithelial cells has been studied to a limited extent and only the up-regulation of IL-8 has been demonstrated and studied mechanistically [41], revealing significant differences to monocyte responses.

In this report we have shown that LL-37 is also able to induce IL- 6 release, but not IL-1 $\beta$ or TNF- $\alpha$, in $16 \mathrm{HBE} 14 \mathrm{o}^{-}$and primary NHBE epithelial cells in a doseand time-dependent manner (fig. 1, 2). Furthermore, LL-37-mediated stimulation occurred at the level of IL- 6 gene expression in a time-dependent manner in $16 \mathrm{HBE} 14 \mathrm{o}^{-}$cells. It was particularly interesting to observe the induction of IL- 6 , but not IL- $1 \beta$ and TNF- $\alpha$, since this cytokine group is commonly induced as part of

J Innate Immun 2009;1:254-267 
a general pro-inflammatory response mediated, at least in part, through the same signalling pathways, including the NF- $\kappa B$ activation pathway. The demonstrated absence of potential IL-1 $\beta /$ TNF- $\alpha$ autocrine stimulation and absence of induction of any cytokines by LPS (ruling this out as a contaminant) indicate that this IL- 6 response is specific to LL-37 stimulation, and not a secondary effect.

IL-6 is a particularly interesting cytokine with respect to lung immunity. An increase in IL- 6 secretion and expression has been described in several lung conditions, such as cystic fibrosis, COPD and the acute respiratory distress syndrome $[65,70,71]$. In the lung, IL- 6 can act as a pro-inflammatory or anti-inflammatory agent, depending on the stimulus and inflammation context. For example while the potent pro-inflammatory response to bacterial TLR agonists often involves the up-regulation of IL- 6 , IL- $1 \beta$ and TNF- $\alpha$, results from a model of systemic endotoxaemia in an IL-6 knock-out mouse and in an endotoxic lung model indicate that IL- 6 plays a crucial anti-inflammatory role [72]. Thus LL-37-mediated IL-6 could act as a mediator that contributes to the maintenance of a delicate inflammatory balance in the lung. Several studies have described IL-6-mediated protection against lung injury and induction of angiogenesis [73, 74].

In airway epithelial cells, TLR agonists such as bacterial flagellin, IL-1 $\beta$ and TNF- $\alpha$, but not bacterial LPS, have been shown to mediate NF- $\kappa \mathrm{B}$ activation $[56,61$, $75]$. This NF- $\kappa \mathrm{B}$ activation in the lung mucosa has been described to regulate a multitude of responses including cytokine regulation (e.g. IL-6, IL-8, IL-1 $\beta$ and TNF- $\alpha$ ), chemokine regulation (e.g. IL-8, GRO- $\alpha$ and RANTES), adhesion molecule expression and other processes central to inflammatory responses [75].

Previous studies demonstrated that IL-8 production in epithelial cells in response to LL-37 stimulation was dependent on ERK1/2 and p38 MAP kinase activation stimulated downstream of EGFR transactivation [39, 41], whereas IL-6 production, as shown here, was only partially dependent on this signaling (fig. 4c). In this report, we have demonstrated for the first time the obligate contribution of activated NF- $\kappa \mathrm{B}$ signalling in LL-37-mediated IL- 6 production in airway epithelial cells. Phosphorylation of IK-B $\alpha$ is a signal that induces ubiquitin-mediated proteasome degradation of this regulator, and this degradation allows NF- $\kappa \mathrm{B}$ subunits sequestered in the cytosol to migrate to the nucleus and activate the transcription of many genes, including IL-6 [76]. In addition to demonstrating LL-37-induced Iк-B $\alpha$ phosphorylation and total Ік-B $\alpha$ degradation (fig. 5), it was shown here that LL-37 stimulation of airway epithelial cells caused NF- $\kappa$ B p50 and p65 subunit nuclear translocation (fig. 6). Inhibitor studies supported the conclusion that this NF$\kappa \mathrm{B}$ signalling activation was required for LL-37-stimulated IL- 6 release (fig. $4 a, b)$.

In airway epithelial cells, the significance of NF- $\kappa$ B signalling in the production and regulation of IL- 6 was previously demonstrated $[55,56,77]$. A detailed analysis of the regulatory region of the IL- 6 gene shows putative binding sites for a variety of response regulators, including NF- $\kappa$ B, AP-1, CREB and NF-IL-6 [78-80], an observation consistent with the possibility that IL- 6 transcriptional regulation requires a complex of transcriptional factors for optimal expression. Evidence supporting the putative involvement of multiple transcription factors in LL-37-mediated regulation of chemokine production comes from monocytic cell/PBMC studies where activation of Elk-1, NF- $\mathrm{kB}$ and CREB was demonstrated [39, 42], while activation of STAT transcription factor was shown in keratinocytes [33]. Thus, it appears that host defence peptide LL-37 induces its immunomodulatory effects through a complex mechanism. It is not possible to speculate which up-stream signaling pathways regulate this LL-37-mediated NF- $\mathrm{BB}$ activation in airway epithelial cells. Our own inhibitor studies indicated that EGFR, p38 and ERK1/2 signaling pathways each contribute only partially to IL-6 regulation (fig. 4c), in contrast to the much stronger effects observed on other LL-37-induced immunomodulatory effects and to the complete inhibition by NF- $\mathrm{KB}$ inhibitors of LL-37-mediated IL- 6 production by epithelial cells (fig. $4 \mathrm{a}, \mathrm{b}$ ). The effect of a $\mathrm{P}_{2} \mathrm{X}_{7}$ inhibitor KN-62 was also tested, however no significant effect on IL-6 production was observed (data not shown). These results thus imply an involvement of EGFR and/or MAPK pathways upstream of NF- $\kappa \mathrm{B}$ activation, but favour the possibility that either they have an indirect effect or are one of several convergent pathways that impact on NF- $\kappa \mathrm{B}$ activation.

It is worth mentioning that a role for NF- $\kappa \mathrm{B}$ has already been described with respect to LL-37-mediated immunomodulation, although not in epithelial cells. For example, inhibitor studies showed NF- $\kappa \mathrm{B}$ regulation in endothelial cell activation and angiogenesis [34]. In a monocytic cell line, LL-37 was shown to inhibit LPSstimulated nuclear translocation of various NF- $\kappa \mathrm{B}$ subunits, which was proposed to be one of the mechanisms by which LL-37 suppresses LPS-induced gene transcription and exerts an anti-endotoxin effect [27]. In contrast, LL-37 stimulation alone has been described to induce the 
transient phosphorylation of Iк-B $\alpha$ and nuclear translocation of $\mathrm{p} 50$ and $\mathrm{p} 65 \mathrm{NF}-\kappa \mathrm{B}$ subunits in primary PBMCs [42]. The LL-37-mediated activation of the NF- $\kappa$ B signalling pathway in airway epithelial cells is a novel effect of this host defence peptide. Indeed, NF- $\kappa \mathrm{B}$ regulation proved to be the pivotal regulation mechanism with respect to selective peptide-mediated IL-6 production.

Flagellin-mediated activation of TLR5 signalling in lung epithelial cells has been demonstrated to induce transient cytosolic calcium increase, PI3K and MAPK signalling, and subsequent NF- $\kappa \mathrm{B}$ activation leading to the production of molecules such as IL- 6 and IL- $8[61,62$, 81]. It has been demonstrated that in DCs, LL-37 inhibited flagellin-mediated IL- 6 , TNF- $\alpha$ and IL- 12 production, and that overall it acted to inhibit TLR ligand activation of these cells [38]. Similarly, studies in monocytic cells/macrophages further describe this inhibitory effect on other TLR ligand-mediated responses [27, 28]. In airway epithelial cells however, co-stimulation with flagellin and LL-37 over a range of doses augmented the cytokine/chemokine signature of these cells. As shown in figure 7, IL-6 was significantly augmented when both stimuli were applied together. Similarly, enhanced production was observed with IL- 8 and GRO- $\alpha$ (data not shown). It thus appears that in the context of lung epithelial innate immunity, LL-37 acts cooperatively to enhance the immune response mediated by flagellin-TLR5 pathway responses. Thus LL-37 acts as a co-stimulatory agent to increase the sensitivity to flagellin-mediated inflammatory response in the lung and would therefore lead to a more stringent host defence response. Signaling pathway regulation underlying the co-stimulatory IL-6 in- duction in primary lung epithelial cells appears to involve the same/similar pathways as for flagellin-mediated induction (fig. 8). Previously, the role of p38 in flagellinmediated signaling has been described in lung epithelial cells $[62,81]$, while the involvement of the PI3 pathway was described in colonic epithelial cells [82]. Given that LL-37-mediated IL- 6 production was shown to be NF- $\kappa$ B regulated (fig. $4 \mathrm{a}, \mathrm{b}$ ), it is possible that LL-37/flagellin stimulation results in additive augmentation of NF- $\kappa B$ stimulation.

As indicated by an increasing number of studies, LL37 is a potent modulator of immune responses of various effector cells. In this study we report another facet of LL37 function in lung innate responses. In addition to the previously described IL-8 induction via EGFR and MAPK activation [39, 41], we report here that LL-37 can activate one of the pivotal regulatory pathways in innate immune responses - NF- $\kappa \mathrm{B}$, which controls peptide-mediated IL6 induction in airway epithelial cells. Furthermore, we report an augmenting effect of LL-37 on responses to the TLR5 ligand flagellin on cytokine production in these cells.

\section{Acknowledgements}

Financial support was obtained from Genome BC and Genome Prairie for the Pathogenomics of Innate Immunity Research Program. R.E.W. Hancock is the recipient of a Canada Research Chair. N.C.J. Filewod is a recipient of an NSERC CGS M and an MSFHR Junior Trainee Award. We gratefully acknowledge technical advice and assistance provided by Silvana Doria, Pegah Miri and Sheena N.Y. Tam.

\section{References}

1 Hancock REW: Cationic peptides: effectors in innate immunity and novel antimicrobials. Lancet 2001;i:156-164.

- Hancock REW, Diamond G: The role of cationic antimicrobial peptides in innate host defences. Trends Microbiol 2000;8:402410.

- 3 Hancock REW, Scott MG: The role of antimicrobial peptides in animal defenses. Proc Natl Acad Sci USA 2000;97:88568861.

4 Jenssen H, Hamill P, Hancock REW: Peptide antimicrobial agents. Clin Microbiol Rev 2006;19:491-511.

5 Agerberth B, Charo J, Werr J, Olsson B, Idali F, Lindbom L, Kiessling R, Jornvall $\mathrm{H}$, Wigzell H, Gudmundsson GH: The human antimicrobial and chemotactic peptides LL-
37 and alpha-defensins are expressed by specific lymphocyte and monocyte populations. Blood 2000;96:3086-3093.

6 Cowland JB, Johnsen AH, Borregaard N: hCAP-18, a cathelin/pro-bactenecin-like protein of human neutrophil specific granules. FEBS Lett 1995;368:173-176.

7 Di Nardo A, Vitiello A, Gallo RL: Cutting edge: mast cell antimicrobial activity is mediated by expression of cathelicidin antimicrobial peptide. J Immunol 2003;170:22742278.

8 Sorensen O, Arnljots K, Cowland JB, Bainton DF, Borregaard N: The human antibacterial cathelicidin, hCAP-18, is synthesized in myelocytes and metamyelocytes and localized to specific granules in neutrophils. Blood 1997;90:2796-2803.
\$9 Wah J, Wellek A, Frankenberger F, Unterberger P, Welsch U, Bals R: Antimicrobial peptides are present in immune and host defense cells of the human respiratory and gastrointestinal tracts. Cell Tissue Res 2006; 324:449-456

10 Bals R, Wang X, Zasloff M, Wilson JM: The peptide antibiotic LL-37/hCAP-18 is expressed in epithelia of the human lung where it has broad antimicrobial activity at the airway surface. Proc Natl Acad Sci USA 1998; 95:9541-9546.

11 Frohm M, Agerberth B, Ahangari G, StahleBackdahl M, Liden S, Wigzell H, Gudmundsson GH: The expression of the gene coding for the antibacterial peptide LL-37 is induced in human keratinocytes during inflammatory disorders. J Biol Chem 1997;272:15258-15263. 
-12 Frohm Nilsson M, Sandstedt B, Sorensen O, Weber G, Borregaard N, Stahle-Backdahl M: The human cationic antimicrobial protein (hCAP18), a peptide antibiotic, is widely expressed in human squamous epithelia and colocalizes with interleukin-6. Infect Immun 1999;67:2561-2566

13 Hase K, Murakami M, Iimura M, Cole SP, Horibe Y, Ohtake T, Obonyo M, Gallo RL, Eckmann L, Kagnoff MF: Expression of LL37 by human gastric epithelial cells as a potential host defense mechanism against $\mathrm{He}$ licobacter pylori. Gastroenterology 2003; 125:1613-1625.

14 Hosokawa I, Hosokawa Y, Komatsuzawa H, Goncalves RB, Karimbux N, Napimoga MH, Seki M, Ouhara K, Sugai M, Taubman MA, Kawai T: Innate immune peptide LL-37 displays distinct expression pattern from betadefensins in inflamed gingival tissue. Clin Exp Immunol 2006;146:218-225.

15 Nell MJ, Tjabringa GS, Vonk MJ, Hiemstra PS, Grote JJ: Bacterial products increase expression of the human cathelicidin hCAP18/LL-37 in cultured human sinus epithelial cells. FEMS Immunol Med Microbiol 2004; 42:225-231.

- 16 Xiao W, Hsu Y-P, Ishizaka A, Kirikae T, Moss RB: Sputum cathelicidin, urokinase plasminogen activation system components, and cytokines discriminate cystic fibrosis, COPD, and asthma inflammation. Chest 2005;128:2316-2326.

17 Agerberth B, Grunewald J, Castanos-Velez E, Olsson B, Jornvall H, Wigzell H, Eklund A, Gudmundsson GH: Antibacterial components in bronchoalveolar lavage fluid from healthy individuals and sarcoidosis patients. Am J Respir Crit Care Med 1999;160:283290.

18 Schaller-Bals S, Schulze A, Bals R: Increased levels of antimicrobial peptides in tracheal aspirates of newborn infants during infection. Am J Respir Crit Care Med 2002;165: 992-995.

-19 Niyonsaba F, Iwabuchi K, Someya A, Hirata M, Matsuda H, Ogawa H, Nagaoka I: A cathelicidin family of human antibacterial peptide LL-37 induces mast cell chemotaxis. Immunology 2002;106:20-26.

20 Tjabringa GS, Ninaber DK, Drijfhout JW, Rabe KF, Hiemstra PS: Human cathelicidin LL-37 is a chemoattractant for eosinophils and neutrophils that acts via formyl-peptide receptors. Int Arch Allergy Immunol 2006; 140:103-112.

-21 Yang D, Chen Q, Schmidt AP, Anderson GM, Wang JM, Wooters J, Oppenheim JJ, Chertov O: LL-37, the neutrophil granule- and epithelial cell-derived cathelicidin, utilizes formyl peptide receptor-like 1 (FPRL1) as a receptor to chemoattract human peripheral blood neutrophils, monocytes, and T cells. J Exp Med 2000;192:1069-1074.

-22 Barlow PG, Li Y, Wilkinson TS, Bowdish DME, Lau YE, Cosseau C, Haslett C, Simpson AJ, Hancock REW, Davidson DJ: The human cationic host defense peptide LL-37 mediates contrasting effects on apoptotic pathways in different primary cells of the innate immune system. J Leukoc Biol 2006;80: 509-520.

-23 Lau YE, Bowdish DME, Cosseau C, Hancock REW, Davidson DJ: Apoptosis of airway epithelial cells: human serum sensitive induction by the cathelicidin LL-37. Am J Respir Cell Mol Biol 2006;34:399-409.

24 Nagaoka I, Tamura H, Hirata M: An antimicrobial cathelicidin peptide, human CAP18/ LL-37, suppresses neutrophil apoptosis via the activation of formyl-peptide receptorlike 1 and $\mathrm{P} 2 \mathrm{X}_{7}$. J Immunol 2006;176:30443052.

25 Chen X, Niyonsaba F, Ushio H, Nagaoka I, Ikeda S, Okumura K, Ogawa H: Human cathelicidin LL-37 increases vascular permeability in the skin via mast cell activation, and phosphorylates MAP kinases p38 and ERK in mast cells. J Dermatol Sci 2006;43:6366.

26 Yoshioka M, Fukuishi N, Kubo Y, Yamanobe H, Ohsaki K, Kawasoe Y, Murata M, Ishizumi A, Nishii Y, Matsui N, Akagi M: Human cathelicidin CAP18/LL-37 changes mast cell function toward innate immunity. Biol Pharm Bull 2008;31:212-216.

27 Mookherjee N, Brown KL, Bowdish DME, Doria S, Falsafi R, Hokamp K, Roche FM, Mu R, Doho GH, Pistolic J, Powers J-P, Bryan J, Brinkman FSL, Hancock REW: Modulation of the TLR-mediated inflammatory response by the endogenous human host defense peptide LL-37. J Immunol 2006;176: 2455-2464.

-28 Scott MG, Vreugdenhil ACE, Buurman WA, Hancock REW, Gold MR: Cutting edge: cationic antimicrobial peptides block the binding of lipopolysaccharide (LPS) to LPS binding protein. J Immunol 2000;164:549-553.

29 Bowdish DME, Davidson DJ, Hancock REW: A re-evaluation of the role of host defence peptides in mammalian immunity. Curr Prot Pept Sci 2005;6:35-51.

30 Niyonsaba F, Ushio H, Nakano N, Ng W, Sayama K, Hashimoto K, Nagaoka I, Okumura K, Ogawa H: Antimicrobial peptides human $\beta$-defensins stimulate epidermal keratinocyte migration, proliferation and production of proinflammatory cytokines and chemokines. J Invest Dermatol 2007;127: 594-604.

- 31 Shaykhiev R, Beisswenger C, Kandler K, Senske J, Puchner A, Damm T, Behr J, Bals R: Human endogenous antibiotic LL-37 stimulates airway epithelial cell proliferation and wound closure. Am J Physiol Lung Cell Mol Physiol 2005;289:L842-848.

32 Yang YH, Wu WKK, Tai EKK, Wong HPS, Lam EKY, So WHL, Shin VY, Cho CH: The cationic host defense peptide rCRAMP promotes gastric ulcer healing in rats. J Pharmacol Exp Ther 2006;318:547-554.

33 Tokumaru S, Sayama K, Shirakata Y, Komatsuzawa $\mathrm{H}$, Ouhara K, Hanakawa Y, Yahata Y, Dai X, Tohyama M, Nagai H, Yang L, Higashiyama S, Yoshimura A, Sugai M, Hashi- moto K: Induction of keratinocyte migration via transactivation of the epidermal growth factor receptor by the antimicrobial peptide LL-37. J Immunol 2005; 175:4662-4668.

- 34 Koczulla R, von Degenfeld G, Kupatt C, Krotz F, Zahler S, Gloe T, Issbrucker K, Unterberger P, Zaiou M, Lebherz C, Karl A, Raake P, Pfosser A, Boekstegers P, Welsch U, Hiemstra PS, Vogelmeier C, Gallo RL, Clauss $\mathrm{M}, \mathrm{Bals} \mathrm{R}$ : An angiogenic role for the human peptide antibiotic LL-37/hCAP-18. J Clin Invest 2003;111:1665-1672.

35 Berkestedt I, Nelson A, Bodelsson M: Endogenous antimicrobial peptide LL-37 induces human vasodilatation. Br J Anaesth 2008; 100:803-809.

36 Carretero M, Escamez MJ, Garcia M, Duarte B, Holguin A, Retamosa L, Jorcano JL, Rio $\mathrm{MD}$, Larcher F: In vitro and in vivo wound healing-promoting activities of human cathelicidin LL-37. J Invest Dermatol 2007;128: 223-236.

37 Davidson DJ, Currie AJ, Reid GSD, Bowdish DME, MacDonald KL, Ma RC, Hancock REW, Speert DP: The cationic antimicrobial peptide LL-37 modulates dendritic cell differentiation and dendritic cell-induced T cell polarization. J Immunol 2004;172:11461156.

38 Kandler K, Shaykhiev R, Kleemann P, Klescz F, Lohoff M, Vogelmeier C, Bals R: The antimicrobial peptide LL-37 inhibits the activation of dendritic cells by TLR ligands. Int Immunol 2006;18:1729-1736.

-39 Bowdish DME, Davidson DJ, Speert DP, Hancock REW: The human cationic peptide LL-37 induces activation of the extracellular signal-regulated kinase and p 38 kinase pathways in primary human monocytes. J Immunol 2004;172:3758-3765.

40 Niyonsaba F, Ushio H, Nagaoka I, Okumura $\mathrm{K}$, Ogawa $\mathrm{H}$ : The human $\beta$-defensins $(-1,-2$, $-3,-4)$ and cathelicidin LL-37 induce IL-18 secretion through $\mathrm{p} 38$ and ERK MAPK activation in primary human keratinocytes. J Immunol 2005;175:1776-1784.

41 Tjabringa GS, Aarbiou J, Ninaber DK, Drijfhout JW, Sorensen OE, Borregaard N, Rabe KF, Hiemstra PS: The antimicrobial peptide LL-37 activates innate immunity at the airway epithelial surface by transactivation of the epidermal growth factor receptor. J Immunol 2003;171:6690-6696.

42 Yu J, Mookherjee N, Wee K, Bowdish D, Pistolic J, Li Y, Rehaume L, Hancock REW: Host defence peptide LL-37, in synergy with inflammatory mediator IL-1B, augments immune responses by multiple pathways. J Immunol 2007;179:7684-7691.

43 Zuyderduyn S, Ninaber DK, Hiemstra PS, Rabe KF: The antimicrobial peptide LL-37 enhances IL-8 release by human airway smooth muscle cells. J Allergy Clin Immunol 2006;117:1328-1335.

44 Zhang Z, Cherryholmes G, Shively JE: Neutrophil secondary necrosis is induced by LL37 derived from cathelicidin. J Leukoc Biol 2008:84:780-788. 
45 Zheng Y, Niyonsaba F, Ushio H, Nagaoka I, Ikeda S, Okumura K, Ogawa H: Cathelicidin LL-37 induces the generation of reactive oxygen species and release of human beta-defensins from neutrophils. Br J Dermatol 2007; 157:1124-1131.

-46 Bals R, Weiner DJ, Meegalla RL, Wilson JM: Transfer of a cathelicidin peptide antibiotic gene restores bacterial killing in a cystic fibrosis xenograft model. J Clin Invest 1999; 103:1113-1117.

-47 Bals R, Weiner DJ, Moscioni AD, Meegalla RL, Wilson JM: Augmentation of innate host defense by expression of a cathelicidin antimicrobial peptide. Infect Immun 1999;67: 6084-6089.

-48 Lau YE, Rozek A, Scott MG, Goosney DL, Davidson DJ, Hancock REW: Interaction and cellular localization of the human host defense peptide LL-37 with lung epithelial cells. Infect Immun 2005;73:583-591.

- 49 Elssner A, Duncan M, Gavrilin M, Wewers MD: A novel $\mathrm{P} 2 \mathrm{X}_{7}$ receptor activator, the human cathelicidin-derived peptide LL37, induces IL- $1 \beta$ processing and release. J Immunol 2004;172:4987-4994.

-50 Cozens AL, Yezzi MJ, Kunzelmann K, Ohrui T, Chin L, Eng K, Finkbeiner WE, Widdicombe JH, Gruenert DC: CFTR expression and chloride secretion in polarized immortal human bronchial epithelial cells. Am J Respir Cell Biol 1994;10:38-47.

51 Darveau RP, Hancock RE: Procedure for isolation of bacterial lipopolysaccharides from both smooth and rough Pseudomonas aeruginosa and Salmonella typhimurium strains. J Bacteriol 1983;155:831-838.

52 Pfaffl MW: A new mathematical model for relative quantification in real-time RT-PCR. Nucleic Acids Res 2001;29:e45.

-53 Luo G, Hershko DD, Robb BW, Wray CJ, Hasselgren PO: IL- $1 \beta$ stimulates IL- 6 production in cultured skeletal muscle cells through activation of MAP kinase signaling pathway and NF- $\kappa$ B. Am J Physiol Regul Integr Comp Physiol 2003;284:R1249-1254.

54 Vanden Berghe W, Vermeulen L, De Wilde G, De Bosscher K, Boone E, Haegeman G: Signal transduction by tumor necrosis factor and gene regulation of the inflammatory cytokine interleukin-6. Biochem Pharmacol 2000;60:1185-1195.

- 55 Becker S, Quay J, Koren HS, Haskill JS: Constitutive and stimulated MCP-1, GRO alpha, beta, and gamma expression in human airway epithelium and bronchoalveolar macrophages. Am J Physiol Lung Cell Mol Physiol 1994;266:L278-L286.

-56 Wang CB, Wong CK, Ip WK, Li MLY, Tian YP, Lam CWK: Induction of IL-6 in co-culture of bronchial epithelial cells and eosinophils is regulated by p38 MAPK and NF-кB. Allergy 2005;60:1378-1385.
57 Everhart MB, Han W, Sherrill TP, Arutiunov M, Polosukhin VV, Burke JR, Sadikot RT, Christman JW, Yull FE, Blackwell TS: Duration and intensity of NF- $\kappa \mathrm{B}$ activity determine the severity of endotoxin-induced acute lung injury. J Immunol 2006;176: 4995-5005.

58 Muir A, Soong G, Sokol S, Reddy B, Gomez MI, van Heeckeren A, Prince A: Toll-like receptors in normal and cystic fibrosis airway epithelial cells. Am J Respir Cell Mol Biol 2004;30:777-783.

59 Ritter M, Mennerich D, Weith A, Seither P: Characterization of Toll-like receptors in primary lung epithelial cells: strong impact of the TLR3 ligand poly(I:C) on the regulation of Toll-like receptors, adaptor proteins and inflammatory response. J Inflamm (Lond) 2005;2:16.

60 Levine SJ: Bronchial epithelial cell-cytokine interactions in airway inflammation. I Invest Med 1995;43:241-249.

61 Tseng J, Do J, Widdicombe JH, Machen TE: Innate immune responses of human tracheal epithelium to Pseudomonas aeruginosa flagellin, TNF- $\alpha$, and IL-1 $\beta$. Am J Physiol Cell Physiol 2006;290:C678-C690.

62 Prince A: Flagellar activation of epithelial signaling. Am J Respir Cell Mol Biol 2006;34: 548-551.

63 Ong PY, Ohtake T, Brandt C, Strickland I, Boguniewicz M, Ganz T, Gallo RL, Leung DYM: Endogenous antimicrobial peptides and skin infections in atopic dermatitis. $\mathrm{N}$ Engl J Med 2002;347:1151-1160.

64 Dorschner RA, Pestonjamasp VK, Tamakuwala S, Ohtake T, Rudisill J, Nizet V, Agerberth B, Gudmundsson GH, Gallo RL: Cutaneous injury induces the release of cathelicidin anti-microbial peptides active against group A Streptococcus. J Invest Dermatol 2001;117:91-97.

65 Kim ST, Cha HE, Kim DY, Han GC, Chung YS, Lee YJ, Hwang YJ, Lee HM: Antimicrobial peptide LL-37 is upregulated in chronic nasal inflammatory disease. Acta Otolaryngol 2003;123:81-85.

66 Chen CIU, Schaller-Bals S, Paul KP, Wahn U, Bals R: Beta-defensins and LL-37 in bronchoalveolar lavage fluid of patients with cystic fibrosis. J Cyst Fibros 2004;3:45-50.

-67 Scott MG, Davidson DJ, Gold MR, Bowdish D, Hancock REW: The human antimicrobial peptide LL-37 is a multifunctional modulator of innate immune responses. J Immunol 2002;169:3883-3891.

68 Tjabringa GS, Rabe KF, Hiemstra PS: The human cathelicidin LL-37: a multifunctional peptide involved in infection and inflammation in the lung. Pulm Pharmacol Ther 2005; 18:321-327.

69 Huang LC, Petkova TD, Reins RY, Proske RJ, McDermott AM: Multifunctional roles of human cathelicidin LL-37 at the ocular surface. Invest Ophthalmol Vis Sci 2006;47: 2369-2380.
70 Arlene AS, Gayle K, Keizo T, Richard MB, Ryszard D, Timothy SB, John WC, Kenneth LB: Dysregulated cytokine production in human cystic fibrosis bronchial epithelial cells. Inflammation 2001;V25:145-155.

71 Martin TR: Lung cytokines and ARDS: Roger S. Mitchell Lecture. Chest 1999;116(1 suppl):2S-8S.

72 Xing Z, Gauldie J, Cox G, Baumann H, Jordana M, Lei X-F, Achong MK: IL-6 is an antiinflammatory cytokine required for controlling local or systemic acute inflammatory responses. J Clin Invest 1998;101: 311-320.

73 Jones SA: Directing transition from innate to acquired immunity: defining a role for IL-6. J Immunol 2005;175:3463-3468.

74 McClintock JY, Wagner EM: Role of IL-6 in systemic angiogenesis of the lung. J Appl Physiol 2005;99:861-866.

75 Christman JW, Sadikot RT, Blackwell TS: The role of nuclear factor- $\kappa \mathrm{B}$ in pulmonary diseases. Chest 2000;117:1482-1487.

76 Ghosh S, May MJ, Kopp EB: NF-кB and REL proteins: evolutionarily conserved mediators of immune responses. Annu Rev Immunol 1998;16:225-260.

77 Ning W, Choi AMK, Li C: Carbon monoxide inhibits IL-17-induced IL-6 production through the MAPK pathway in human pulmonary epithelial cells. Am J Physiol Lung Cell Mol Physiol 2005;289:L268-273.

78 Baccam M, Woo S-Y, Vinson C, Bishop GA: CD40-mediated transcriptional regulation of the IL- 6 gene in B lymphocytes: involvement of NF- $\mathrm{B}, \mathrm{AP}-1$, and C/EBP. J Immunol 2003;170:3099-3108.

79 Dendorfer U, Oettgen P, Libermann TA: Multiple regulatory elements in the interleukin- 6 gene mediate induction by prostaglandins, cyclic AMP, and lipopolysaccharide. Mol Cell Biol 1994;14:4443-4454.

80 Matsusaka T, Fujikawa K, Nishio Y, Mukaida $\mathrm{N}$, Matsushima K, Kishmoto T, Akira S: Transcription factors NF-IL6 and NF- $\kappa B$ synergistically activate transcription of the inflammatory cytokines, interleukin 6 and interleukin 8. Proc Natl Acad Sci 1993;90: 10193-10197.

-81 Zhang Z, Reenstra W, Weiner DJ, Louboutin J-P, Wilson JM: The p38 mitogen-activated protein kinase signaling pathway is coupled to Toll-like receptor 5 to mediate gene regulation in response to Pseudomonas aeruginosa infection in human airway epithelial cells. Infect Immun 2007;75:5985-5992.

82 Rhee SH, Kim H, Moyer MP, Pothoulakis C: Role of MyD88 in phosphatidylinositol 3-kinase activation by flagellin/Toll-like receptor 5 engagement in colonic epithelial cells. J Biol Chem 2006;281:18560-18568. 